\title{
Terminal valuations, growth rates and the implied cost of capital
}

\author{
David Ashton • Pengguo Wang
}

Published online: 14 August 2012

(C) The Author(s) 2012. This article is published with open access at Springerlink.com

\begin{abstract}
We develop a model based on the notion that prices lead earnings, allowing for a simultaneous estimation of the implied growth rate and the cost of equity capital for US industrial sectors. The major difference between our approach and that in prior literature is that ours avoids the necessity to make assumptions about terminal values and consequently about future growth rates. In fact, growth rates are an endogenous variable, which is estimated simultaneously with the implied cost of equity capital. Since we require only 1-year-ahead forecasts of earnings and no assumptions about dividend payouts, our methodology allows us to estimate ex ante aggregate growth and risk premia over a larger sample of firms than has previously been possible. Our estimate of the risk premium being between 3.1 and $3.9 \%$ is at the lower end of recent estimates, reflecting the inclusion of these short-lived companies. Our estimate of the long run growth is from 4.2 to $4.7 \%$.
\end{abstract}

Keywords Cost of capital $\cdot$ Risk premium - Growth rate $\cdot$ Earnings forecasts

JEL Classification $\mathrm{G} 12 \cdot \mathrm{G} 14 \cdot \mathrm{G} 17 \cdot \mathrm{G} 31 \cdot \mathrm{M} 41$

\section{Introduction}

The concept of the expected return to equity is a core idea in financial economics. However, due to its directly unobservable nature, proxies are normally used by both academics and practitioners. The two most common proxies are some statistic based

\footnotetext{
D. Ashton

Department of Accounting and Finance, Bristol University, Bristol BS8 1TN, UK

e-mail: david.ashton@bristol.ac.uk

P. Wang (凶)

XFi Centre for Finance and Investment, Exeter University Business School, Exeter EX4 4ST, UK e-mail: p.wang@exeter.ac.uk
} 
on past realized returns or an estimate based on the implied cost of equity capital deduced from analysts' forecasts. Although returns over the long run provide an estimate of expected returns, "realized returns are a very poor measure of expected returns" (Elton 1999). The expected return varies over time "because a high realized return often signals that the expected return is falling rather than the expected return is high" (Pastor et al. 2008). While one appealing feature of the implied cost of equity capital as a proxy for expected returns is that it does not rely on the noisy history of realized asset returns, the infinite series of expected future flows from an asset is invariably truncated using a terminal valuation. Hence the precision of this implied cost of capital estimate is potentially very dependent on the assumed rate of growth in perpetuity of the future flows inherent in the construction of this terminal valuation. Analysts' forecasts of earnings and the emergent price consequent on those forecasts not only imply a discount rate for earnings, a cost of capital, but also implicit assumptions about the future growth rate in those earnings. In contrast this future growth rate is the subject of various ad hoc assumptions in the existing literature.

Apart from differences in the assumed post-horizon behavior of earnings or residual income, the methods used to estimate the implied cost of capital differ, inter alia, in respect of the assumptions made about the structure of the equity valuation model and about the dividend policy pursued. For instance, Gordon and Gordon (1997) impose the assumption that a firm's return on equity (ROE) converges to its cost of equity capital beyond a 4-year forecast horizon. Gebhardt et al. (2001) and Liu et al. (2002) assume that from year 4 to year 12 the firm's return on investment converges to the industry median in a linear fashion and then remains constant in perpetuity. In addition, firms are assumed to have a $100 \%$ dividend payout ratio beyond the forecast horizon. ${ }^{1}$ Claus and Thomas (2001) assume residual earnings grow at the expected inflation rate after a 5-year forecast horizon and assume that $50 \%$ of earnings are retained each period. Botosan and Plumlee (2002) avoid explicit forecasts of future growth rates by using a Value Line forecast as the year-5 terminal value. Implicitly they are assuming that analysts' forecasts and the market's forecasts of terminal value are consistent. Gode and Mohanram (2003) applying the Ohlson and Juettner-Nauroth (2005) model assume that a firm's growth in residual income reverts to an economy-wide level, which they equate to the risk free rate less $3 \%$ beyond the forecast horizon. They also assume a different shortterm growth in earnings equal to the average of the forecast 2-year growth and 5-year growth.

In view of the many approaches adopted, it is perhaps not surprising that the estimated equity-risk premium, the difference between the expected equity return and a risk-free rate, has ranged from a negative number to more than $12 \%$. While the estimates summarizing data from 1926 provided by Ibbotson Associates may be the most widely used proxy for the equity premium derived from historical returns, this proxy seems to be much higher than most recent findings based on estimates of

\footnotetext{
${ }^{1}$ Both Gebhardt et al. (2001) and Liu et al. (2002) use a residual income valuation model to deduce the cost of capital, and both rely on the estimation of the industry median of ROE. Their results show that the cost of capital estimates are sensitive to how one deals with loss firms when calculating the industry median ROE.
} 
the implied cost of equity capital. ${ }^{2}$ For example, comparing and contrasting five different approaches to generating estimates of the implied cost of equity capital, Botosan and Plumlee (2005) find that the risk premium varies from a low of $1 \%$ to a high of $6.6 \%$, while the average realized premium during their sample period is $12.5 \%$. While Easton et al. (2002) and Gode and Mohanram (2003) find the equity risk premium to be between 5 and $6 \%$, others believe that equity risk premium is between 2 and $4 \%$ (for example, Bogle 1999; Claus and Thomas 2001; Gebhardt et al. 2001; Pastor et al. 2008). ${ }^{3}$ Some researchers even suggest that the premium is close to zero (for example, Mehra and Prescott 1985; Glassman and Hassett 1998; Easton and Sommers 2007). Welch (2000) finds that the declining dividend yields have caused predicted equity premium to turn negative. ${ }^{4}$ In contrast to the approach adopted in this paper, few studies have developed broad based estimates of the variation in the growth rate and the cost of equity capital and hence the risk premium on a year by year basis over a 30 -year period.

Almost all studies of the implied cost of capital take the growth rate in the terminal valuation as an exogenous parameter. The only prior attempts to estimate simultaneously the implied cost of capital and growth are to be found in the papers by Easton et al. (2002), Easton (2004), and Nekrasov and Ogneva (2011). ${ }^{5}$ The approach proposed in this paper, however, differs from Easton et al. (2002) and Easton (2004) in a number of important aspects. First, the interpretation of growth is different; second, we adopt a less restrictive model for the valuation of equity. We assume a simple conceptual valuation model in which prices can be expressed as a linear function of current accounting fundamentals plus an unspecified variable summarizing information not captured by this linear accounting function; third, we require only 1-year-ahead forecasts of earnings, which supposedly are more reliable than longer-term forecasts. In contrast to Easton et al. (2002), we do not need to assume that the implied growth rate and the growth rate in residual earnings are the same: the growth rate in our context can be interpreted as growth in the value of a firm's stock rather than its residual earnings. We also do not require up to 4 years of earnings forecasts and thus avoid the need to treat the 4-year residual earnings as a perpetuity. The relaxation of these two restrictions effectively avoids the necessity of making explicit assumptions about the structure of the terminal valuation. Furthermore, we do not assume, as do Easton et al. (2002), that the expected dividends in the subsequent 4 years are equal to dividends paid at current fiscal year end (year 0). In a later paper, Easton (2004) also estimates a growth parameter,

\footnotetext{
2 Ibbotson Associates (2006) use 30-day T-bill rate to infer equity premium from observed returns. Others use the 10-year T-bond as the risk-free rate to incorporate long-term future cash flows based on forward-looking approaches. However, the Ibbotson estimates are substantially higher even if one considers the difference between these two risk-free rates.

3 O'Hanlon and Steele (2000) estimate the UK equity premium at $4 \%$ based on a realized earnings model. Dimson et al. (2011) find that, taking US government bonds as the risk-free asset, the annualized risk premium over the period 1926-2006 is $6.6 \%$ and is $5.6 \%$ over the period that we investigate 1975-2006.

4 Siegel and Thaler (1997) provide a good summary of the early literature on equity premium estimations.

5 The paper by Nekrasov and Ogneva (2011) is a refinement of the approach adopted in Easton et al. (2002).
} 
which he defines as "the perpetual rate of change in abnormal growth in earnings." This growth clearly differs from the growth rate of a firm. ${ }^{6}$ It relies on Ohlson and Juettner-Nauroth (2005) model and naturally requires 2 years forecasts of earnings. Again, Easton (2004) assumes a specific dividend payout policy, that is, dividend in year one equals current fiscal year end dividend. In contrast, we develop a model that allows for a simultaneous estimate the growth rate and the cost of equity capital for US industrial sectors. We adopt the simpler assumption that dividends merely displace book values on a dollar for dollar basis and that dividend payout policy is irrelevant. Relaxing the dividend assumption has several benefits. First, it obviates bias induced by simple forecasts of future dividends, residual income, and abnormal growth in earnings. Second the fact that we do not need to make any assumptions about future dividend payouts allows us to include firms with negative forecasted earnings. These assumptions about dividend policy, together with the fact that we do not need earnings forecasts beyond the first year, enable us to estimate ex ante aggregate growth rates and the equity risk premia over a larger sample of firms than has previously been possible. However, the major difference between our approach and that in prior literature is that ours avoids the necessity to make assumptions about the detailed structure of valuation models or about terminal values and hence about future growth rates. This new approach is based on the notion that prices lead earnings and earnings have persistence. Specifically, we show how expected earnings relate to current equity prices and accounting fundamentals. To our knowledge, this is the first model to show this relationship in an analytic form. We also establish the relation between realized returns and the implied cost of capital and one-period-ahead forecasts of earnings. This enables us to discuss the impact of analysts' optimism documented in prior literature on our estimates. Our model also establishes the relationship between the implied cost of equity capital and accounting risk factors, such as earnings-to-price, book-to-price, and dividend yield.

We start by assuming no arbitrage and clean surplus accounting. We then establish a link between equity valuation and analysts' forecasts of 1-year-ahead earnings. Contemporaneous values of price, reported book values, earnings, dividends, and forecasts of the following year earnings form the primary inputs into our model. In the spirit of Easton et al. (2002), the implied cost of capital and growth rate can be inferred by regressing 1-year-ahead forecasts of earnings on prices and other financial statement variables. We use this forward-looking approach to estimate simultaneously the implied cost of capital and the growth rate on both a year-by-year and on an industry-by-industry basis.

Our analysis is based on two variants of our valuation model. One we label as a simple model, and the other we refer to as the extended model. This latter model explicitly incorporates an adjustment for accounting conservatism into the model. The rationale is that growth firms have increased demands for conservatism (Smith and Watts 1992), and growth in investment reduces reported earnings (Penman and Zhang 2002). Apart from estimates of growth, we find that our estimates of cost of capital and risk premia are relatively robust to either of the modeling approaches

\footnotetext{
${ }^{6}$ Estimates of the rate of change in abnormal growth in earnings $\left(g_{a g r}\right)$ in Easton (2004) are often negative (Easton 2009, p. 273).
} 
adopted or the way the data is grouped. Based on available US data over the period 1975-2006, our estimation of the implied cost of capital is in the lower end of the range relative to prior literature. The mean risk premium is between 3.1 and $3.9 \%$, depending on the precise model and data set used. We estimate the mean cost of capital to be between 10.8 and $11.2 \%$ during our sample period.

On the other hand, the mean and median annual expected growth rates during our sample period are respectively 4.2 and $4.0 \%$ on a year-by-year basis. This is much lower than the estimates produced by Easton et al. (2002), which are of the order of $10 \%$. We find closer agreement between our estimated growth rate and the forecasts produced by the Congressional Budget Office. We also find justification in the use by prior studies of the risk free rate minus $3 \%$ as a proxy of long term growth in terminal valuations (Claus and Thomas 2001; Gode and Mohanram 2003). Our average growth forecast not only assumes the same average value of this latter rate but also shows similar fluctuations to this rate when viewed on a year-byyear basis.

The rest of the paper is organized as follows. Section 2 develops our theoretical models for the determination of the cost of equity capital and growth rates. Section 3 describes the sample in our analysis. Section 4 reports the empirical findings and compares our results with prior literature. Section 5 concludes.

\section{Model development and empirical design}

Financial analysts use financial statement information as a primary source of information in the valuation of equity. With this in mind and in the spirit of Ohlson (1995), Feltham and Ohlson (1995, 1996), and Pope and Wang (2005) we can express equity value in terms of both accounting and non-accounting variables in the following simple parsimonious form:

$$
P_{t}=\alpha_{1} b_{t}+\alpha_{2} e_{t}+\alpha_{3} d_{t}+\vartheta_{t},
$$

where the accounting information set includes book value, $b_{t}$, earnings, $e_{t}$, and dividends (net of new capital contributions), $d_{t}$. The variable $\vartheta_{t}$ represents the value attributed by the market to information not captured by the three accounting variables but incorporated into the price. Because accounting numbers represent a firm's historical transactions and prices are normally considered to incorporate future growth of companies, $\vartheta_{t}$ must reflect the nature of the growth component. For the purpose of our analysis, we initially assume the following simple model:

$$
\vartheta_{t+1}=(1+g) \vartheta_{t}+\varepsilon_{v t+1},
$$

where the growth rate, $g$, satisfies $1+g<R ; R$ is one plus the cost of equity capital; $\varepsilon_{v t+1}$ is a mean zero error term. To develop our analysis, we make the following three assumptions. First, capital markets are free of arbitrage opportunity. More specifically we assume prices, $P_{t}$, and dividends, $d_{t}$, are related by $E_{t}\left[P_{t+1}+d_{t+1}\right]=R P_{t}$. Second, we assume that net dividends are equal to earnings subtracting changes in book values of equity, that is, clean surplus accounting applies. Third, consistent with Miller and Modigliani (1961), we assume that it is 
investment policy that determines the value of equity and dividend policy is irrelevant. Specifically, we assume that net dividend flows displace equity price dollarfor-dollar (that is, $\frac{\partial P_{t}}{\partial d_{t}}=-1$ ), and dividend payments reduce owners' equity, $\frac{\partial b_{t}}{\partial d_{t}}=$ -1 , but do not affect current earnings, $\frac{\partial e_{t}}{\partial d_{t}}=0$. In addition, we assume that the value attributed to the "non-accounting" information variable is unaffected by dividend payout, $\frac{\partial \vartheta_{t}}{\partial d_{t}}=0$ (Ohlson 1995; Feltham and Ohlson 1995). These assumptions and Eq. (1) together imply that $\alpha_{3}=\alpha_{1}-1$.

With these assumptions, we can relate our pricing expression [Eq. (1)] in periods $t$ and $t+1$ to generate Eq. (3) (see "Appendix" for the proof):

$$
E_{t}\left[e_{t+1}\right]=\frac{R}{\left(\alpha_{1}+\alpha_{2}\right)} P_{t}-\frac{\alpha_{1}}{\left(\alpha_{1}+\alpha_{2}\right)} b_{t}-\frac{(1+g)}{\left(\alpha_{1}+\alpha_{2}\right)} \vartheta_{t} .
$$

This equation suggests that prices lead earnings in the sense of that prices can still be useful for predicting subsequent period earnings, given equity book values and non-accounting information. The unspecified non-accounting variable $\vartheta_{t}$ presents an immediate problem in any direct application of this model. However, by substituting $\vartheta_{t}$ from Eq. (1) into Eq. (3) and applying clean surplus accounting, we have the following earnings forecasting model for estimating the parameters (see "Appendix" for the proof) ${ }^{78}$ :

$$
E_{t}\left[e_{t+1}\right]=\delta_{1} P_{t}+\delta_{2} e_{t}+\delta_{3} b_{t}+\delta_{4} b_{t-1}
$$

where

$$
\begin{aligned}
& \delta_{1}=\frac{R-(1+g)}{\left(\alpha_{1}+\alpha_{2}\right)}, \\
& \delta_{2}=\frac{(1+g)\left(\alpha_{1}+\alpha_{2}-1\right)}{\left(\alpha_{1}+\alpha_{2}\right)}, \\
& \delta_{3}=\frac{1+g-\alpha_{1}}{\left(\alpha_{1}+\alpha_{2}\right)}, \\
& \delta_{4}=\frac{(1+g)\left(\alpha_{1}-1\right)}{\left(\alpha_{1}+\alpha_{2}\right)} .
\end{aligned}
$$

We note that equation system (5) provides a one-to-one meaningful mapping between these four coefficients, $\delta_{1}-\delta_{4}$, and the four "valuation" parameters. If we regress forecasted earnings on price, earnings, and the two book value terms based on Eq. (4), we can back out the implied cost of capital, growth rate g, $\alpha_{1}$, and $\alpha_{2}$ in terms of the regression coefficients. Specifically, we can write the growth rate, the implied cost of capital, $\alpha_{1}$, and $\alpha_{2}$ in terms of the regression parameters as:

\footnotetext{
${ }^{7}$ We could develop a similar expression using net dividends, but it turns out to be more convenient to work with book values and changes in book value. Unlike most prior studies, we need not calculate forecasted book value based on the clean-surplus assumption on a per share basis. In other words, our model of estimation is initially developed on a total dollar basis.

${ }^{8}$ Easton and Sommers (2007) essentially use a simpler form of our valuation model. Their valuation equation is equivalent to $P_{t}=b_{t}+\frac{E\left[e_{t+1}\right]-\left(R^{E}-1\right) b_{t}}{R^{E}-1-g^{E}}$, which can be written as $E\left[e_{t+1}\right]=\left(R^{E}-1-g^{E}\right) P_{t}+$ $g^{E} b_{t}$. This is a special case in our Eqs. (1) and (5), with $\alpha_{1}=1, \alpha_{2}=0$, and $P_{t}=b_{t}+\vartheta_{t}$.
} 


$$
\begin{aligned}
& 1+g=\frac{\left(1+\delta_{2}+\delta_{3}\right)+\sqrt{\left(1+\delta_{2}+\delta_{3}\right)^{2}-4\left(\delta_{2}-\delta_{4}\right)}}{2}, \\
& R=(1+g)\left(1+\frac{\delta_{1}}{1+g-\delta_{2}}\right) \\
& \alpha_{1}=1+\frac{\delta_{4}}{1+g-\delta_{2}} \\
& \alpha_{2}=\frac{\delta_{2}-\delta_{4}}{1+g-\delta_{2}} .
\end{aligned}
$$

At this stage, note that the growth in the non-accounting variable $\vartheta_{t}$ can be estimated although the variable itself remains a black box. ${ }^{9}$ The growth parameter lends itself to a relatively straightforward interpretation. Cointegration considerations of Eqs. (1) and (2) imply that the growth rate $g$ can be interpreted as the longrun growth of the firm or growth rate in investment in Feltham and Ohlson (1996) framework. ${ }^{10}$ Another way of viewing the growth parameter is to suppose that other information could be reduced to a linear function of all future earnings. In this case, $g$ must be interpreted as the nominal growth in perpetuity of these earnings. We might well expect $g$ to equate on average to the long run nominal growth in GDP. ${ }^{11}$

Prior literature also demonstrates that an element of growth in Eq. (2) is associated with conservatism, since book values and earnings in Eq. (1) are likely to be under-reported, distorting values between conservative and less conservative firms. ${ }^{12}$ We therefore partition our other information variable into a growth element associated with growth in positive NPV investment opportunities and growth coming from variations in the degree of conservatism in reporting. We will measure conservatism by the difference between economic earnings, $\left(P_{t}-P_{t-1}+d_{t}\right)$ and accounting earnings. ${ }^{13}$ Hence we rewrite Eq. (2) as:

\footnotetext{
${ }^{9}$ Once we have estimated $\alpha_{\mathrm{j}}(j=1,2,3)$ in Eq. (1), non-accounting information can be eventually estimated. In fact, we find that the accounting fundamental component is close to $80 \%$ of equity value based on our estimated parameters.

${ }^{10}$ Note that the valuation model summarized in Proposition 2(3a) in Feltham and Ohlson (1996), $P_{t}=o a_{t}+\alpha_{1} o x_{t}^{a}+\alpha_{2} o a_{t-1}+\alpha_{3} c i_{t}$, together with no-arbitrage condition, implies that operating earnings can be expressed in terms of equity price, operating assets, and investment, $o x_{t+1}=\frac{R}{\left(1+\alpha_{1}\right)} P_{t}-\frac{\left(1+\alpha_{2}-\alpha_{1}(R-1)\right)}{\left(1+\alpha_{1}\right)} o a_{t}-\frac{\omega}{\left(1+\alpha_{1}\right)} \alpha_{3} c i_{t}$. This is equivalent to Eq. (3) above. Therefore the positive NPV investment, which grows at a rate $g$, in Feltham and Ohlson (1996) can be viewed as a proxy of our "other information".

11 Lundholm and Sloan (2007) offer a tight guideline for sales/earnings growth rate. They state that "in the past decade, it (the nominal GDP growth rate) has been closer to 5 percent and the Congressional Budget Office estimates 5 percent nominal GPD growth through 2012 (3 percent real growth and 2 percent price inflation)."

12 Claus and Thomas (2001) argue that expected growth is affected by both the expectation of future economic rents and the conservative nature of accounting. The effects of accounting conservatism on the short horizon forecasts of earnings will differ from firm to firm and thus affect the base from which earnings are assumed to grow in perpetuity (Easton 2009).

13 Easton (2009) argues that "(abnormal return on equity) will reflect both real growth and a correction for GAAP differences between short-run forecasts of earnings and economic earnings."
} 


$$
\vartheta_{t+1}=(1+g) \vartheta_{t}+\alpha_{4}\left(P_{t}-P_{t-1}+d_{t}-e_{t}\right)+\varepsilon_{v t+1} .
$$

This leads to an extended earnings forecasting model (see "Appendix" for the proof):

$$
E_{t}\left[e_{t+1}\right]=\delta_{1}^{\prime} P_{t}+\delta_{2}^{\prime} e_{t}+\delta_{3}^{\prime} b_{t}+\delta_{4}^{\prime} b_{t-1}+\delta_{5}^{\prime} P_{t-1},
$$

where

$$
\begin{aligned}
1+g & =\frac{1+\delta_{2}^{\prime}+\delta_{3}^{\prime}-\delta_{5}^{\prime}+\sqrt{\left(1+\delta_{2}^{\prime}+\delta_{3}^{\prime}-\delta_{5}^{\prime}\right)^{2}-4\left(\delta_{2}^{\prime}-\delta_{4}^{\prime}-\delta_{5}^{\prime}\right)}}{2} \\
R & =(1+g)\left(1+\frac{\delta_{1}^{\prime}+\delta_{5}^{\prime}}{1+g-\delta_{2}^{\prime}}\right) \\
\alpha_{1} & =1+\frac{\delta_{4}^{\prime}+\delta_{5}^{\prime}}{(1+g)-\delta_{2}^{\prime}} \\
\alpha_{2} & =\frac{\delta_{2}^{\prime}-\delta_{4}^{\prime}-\delta_{5}^{\prime}}{(1+g)-\delta_{2}^{\prime}} \\
\alpha_{4} & =\frac{(1+g) \delta_{5}^{\prime}}{1+g-\delta_{2}^{\prime}} .
\end{aligned}
$$

In both our models, (4) and (8), all the right-side variables are observable at time $t$, and we can use analysts' earnings forecasts, that is one-period-ahead forecasted earnings to proxy $E\left[e_{t+1}\right]$. We expect $\delta_{1}\left(\delta_{1}^{\prime}\right)>0$ on the assumption that prices lead earnings and expected earnings to have a positive persistence with $\delta_{2}\left(\delta_{2}^{\prime}\right)>0$. We also expect that the growth rate, $g$, estimated from Eq. (9) will be lower than the growth rate estimated using Eq. (5), if growth firms are more conservative and growth in investment reduces reported earnings (Smith and Watts 1992; Penman and Zhang 2002).

We note that Richardson et al. (2010) recently proposed a generalized oneperiod-ahead prediction model of earnings in terms of current period earnings, changes in book value, the lagged book value, and non-accounting information. They suggest that the set of non-accounting information includes information such as current market prices of equity and changes in current market prices. Specifically, they accept that earnings are highly persistent, and, consistent with prior findings, prices and returns on equity are leading indicators of future earnings. In addition, they suggest that changes in book values of equity may also reflect accounting conservatism and accounting accruals. Accordingly, lagged book values may play a critical role in predicting future earnings. Therefore the earning forecast model, (8), in effect is a formalization of the arguments of Richardson et al. (2010). It shows that one-period-ahead earnings can be written as a function of five variables: current earnings, current and lagged book values, and current and lagged equity prices.

\section{Sample description}

Our sample consists of prices and accounting data in the intersection of the Center for Research in Security Prices (CRSP) and Compustat over the period 1974-2006 
and the Institutional Brokers Estimate System (I/B/E/S) between 1976 and 2007. The adjusted numbers of shares outstanding, adjusted price and adjusted dividends at the end of the fiscal year, and adjusted price of equity 3 months after the fiscal year-end are collected from CRSP. Relevant accounting data is collected from Compustat. Firms with negative book values (\#60) are deleted. Earnings are measured as net income before extraordinary items (\#18). We use median consensus forecasts of earnings per share at the first month after the corresponding I/B/E/ $S$-reported prior-year earnings announcements. All variables used in our estimation are divided by the adjusted number of shares in issue to reduce heteroskedasticity and increase comparability across time.

We measure size as the logarithm of a firm's market capitalization and measure leverage as the total debt divided by the firm's market capitalization. The price-tobook ratio is measured by the market value of equity and the book value of equity at the end of the year. Total debt is the sum of long-term debt (\#9) and short-term debt (\#34). In constructing our data set, we omit firms in the extreme percentile of earnings, book value, price, earnings-to-price, return on book equity, size, marketto-book ratio, and leverage, including firms with a price per share less than \$1 (Ball et al. 2000; Khan and Watts 2009). ${ }^{14,15}$ We also winsorize $1 \%$ of forecasted earnings. We provide summary statistics in Table 1.

\section{Empirical results}

\subsection{Implied cost of capital and rate of growth}

The requirement to identify four or five parameters precludes their estimation on an individual firm basis. ${ }^{16}$ Hence we carry out our empirical investigations based on Eqs. (4) and (8) by partitioning our data in two ways. First, we investigate the models on a year-by-year basis using cross-sectional regressions; we then investigate the models on an industry-by-industry basis using a time series crosssectional regression. Our industry classification follows that of Fama and French (1997). In the industry panel analysis, we consider two-way cluster-robust standard errors that are robust to both time-series and cross-sectional correlations (Petersen 2009; Gow et al. 2010). To reduce nonstationarity and minimize the effects of endogeneity, we deflate both sides of Eqs. (4) and (8) by the price 3 months after fiscal year-end to provide contemporaneity with the fiscal year-end reporting of book values and earnings. This transformation of Eqs. (4) and (8) enables us to use directly analysts' forecast of 1-year-ahead earnings per share, feps $s_{t+1}$, and work

\footnotetext{
14 Many penny firms have small market capitalizations. Easton and Sommers (2007) argue that small stocks have an undue effect on the estimate of the market return.

15 Winsorizing the extreme percentiles does not change our main results. We also note that, even after this cut, our sample size is still larger than all similar published studies.

16 This would restrict us to the few firms with 30 continuous years of history. We did estimate the parameters for individual firms with at least 20 observations. Although we found that the average cost of capital was not significantly different, our estimate of the long-run growth rate was significantly higher at around $9 \%$, which may reflect survivorship or success bias.
} 


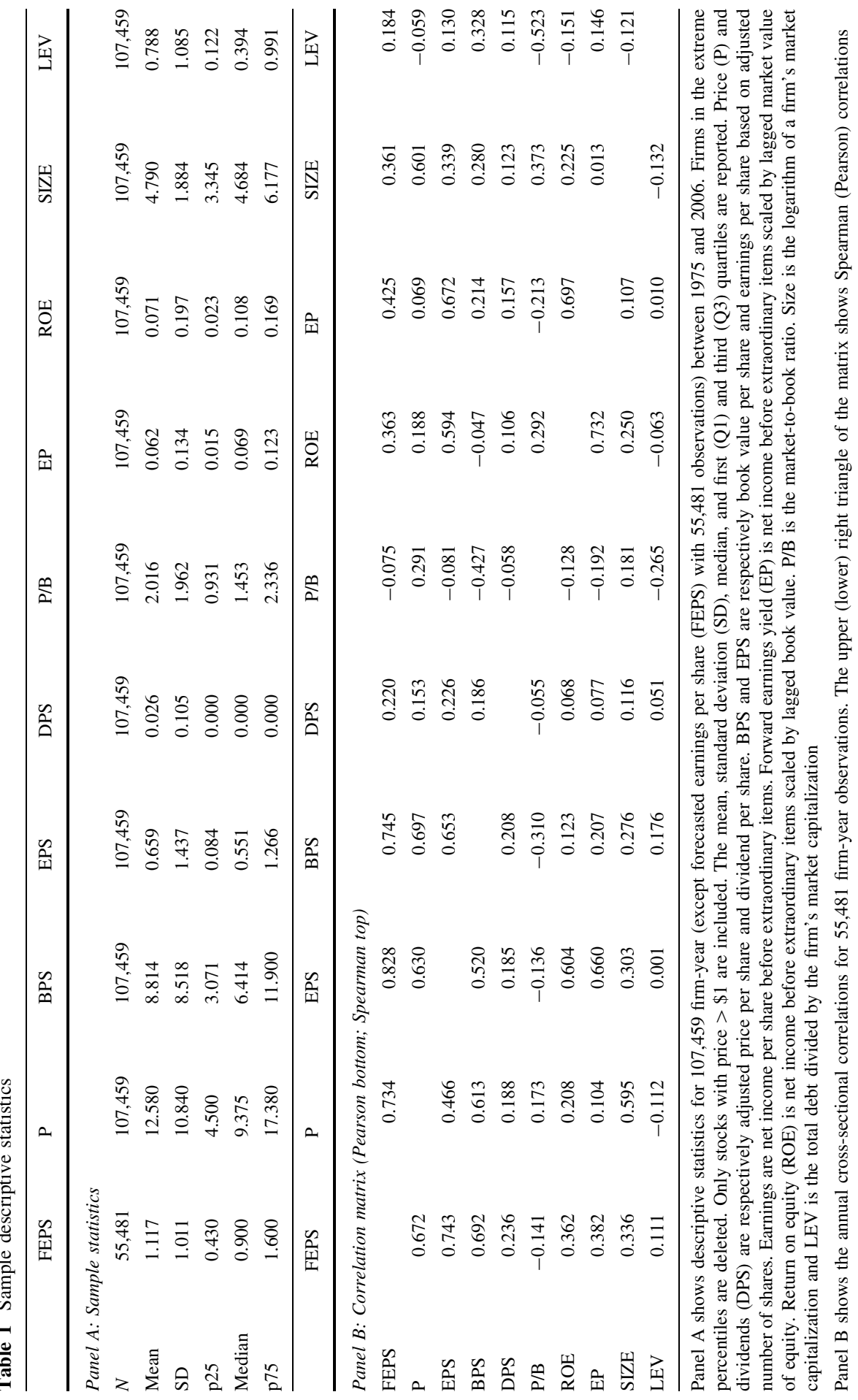


with adjusted per share data. This generates our two test Eqs. (10) and (11), where for ease of reference we will refer to Eq. (10) as the simple model ${ }^{17}$ :

$$
\frac{\text { feps }_{t+1}}{P_{t}}=\delta_{1}+\delta_{2} \frac{e_{t}}{P_{t}}+\delta_{3} \frac{b_{t}}{P_{t}}+\delta_{4} \frac{b_{t-1}}{P_{t}}+\varepsilon_{t+1},
$$

and Eq. (11) the extended model:

$$
\frac{\text { epp }_{t+1}}{P_{t}}=\delta_{1}^{\prime}+\delta_{2}^{\prime} \frac{e_{t}}{P_{t}}+\delta_{3}^{\prime} \frac{b_{t}}{P_{t}}+\delta_{4}^{\prime} \frac{b_{t-1}}{P_{t}}+\delta_{5}^{\prime} \frac{P_{t-1}}{P_{t}}+\varepsilon_{t+1}^{\prime} .
$$

\subsubsection{Analysis on a year-by-year basis}

Our sample size varies over the 32 years from a low of 600 firms in 1975 to a high of 2,573 firms in 1997. The average number of annual observation is 1,734 . We regress forecasted 1-year earnings yields on earnings, book values, lagged book values per share, and lagged prices, all deflated by prices, to obtain the coefficients, $\delta_{i}$ and $\delta_{i}^{\prime}$ from Eqs. (10) and (11). ${ }^{18}$ The descriptive statistics for the parameter estimates in the regression are shown in Table 2.

In Table 2, Panel A, using the simple model based on Eq. (10), we observe that all of the $\delta_{1} \mathrm{~s}$ and $\delta_{2} \mathrm{~s}$ are positive as predicted. We also observe that $\delta_{1}$ is highly significant with regard to explaining 1-year-ahead earnings, confirming that prices lead earnings after controlling for current earnings and book values. We also note that current earnings $\left(\delta_{2}\right)$ are an important predictor of future earnings. Neither the coefficient of lagged book value $\left(\delta_{4}\right)$ nor the coefficient of current book value $\left(\delta_{3}\right)$ is statistically significant. ${ }^{19}$ A similar phenomenon occurs when we examine the extended model in Panel B, where the coefficient $\delta_{1}^{\prime}$ of price $P_{t}$ and the coefficient $\delta_{2}^{\prime}$ of current earnings $e_{t}$ provide the bulk of the explanatory power of forecast earnings. ${ }^{20} \mathrm{We}$ also observe that none of the coefficients of book value $\left(\delta_{3}^{\prime}\right)$, lagged book value $\left(\delta_{4}^{\prime}\right)$, and lagged price $\left(\delta_{5}^{\prime}\right)$ is statistically significant at the $5 \%$ level.

In Table 3, we detail the estimates of cost of capital, growth rates, and risk premia on a year-by-year basis, using both the simple model (Panel A) and the extended model (Panel B). We observe that the mean cost of capital, $11.2 \%$, and risk premium, $3.8 \%$, are virtually identical in the two models. We report risk premia based on 5-year US government bonds yields as proxy for the risk-free rate. Indeed the correlation coefficient between our two estimates from the two models of the cost of capital and the two estimates of the equity risk premium is over 0.99 .

\footnotetext{
17 Since the error terms in Eqs. (10) and (11) may be heteroskedastic, we also use White (1980) corrections to the standard errors in our estimations. Following Easton and Summers (2007) and applying value-weighted regressions, we find that the main results are largely unaltered.

${ }^{18}$ We find that it makes little difference when we introduce dirty surplus earnings in estimating the growth rate and the cost of capital. The estimated growth rate and cost of capital are also robust to the deflator we used, such as market index and lagged price. Our results are also robust with or without intercepts in our regression when we use per share data without deflation.

${ }^{19}$ We also ran all our models using just fiscal year-end prices and found that there was little difference in the results.

${ }^{20}$ When using Newey-West $t$ test on the 32-year time-series estimates, the results are similar.
} 
Table 2 The descriptive statistics for regressing forecasted earnings on price, earnings, book value, lagged book value, and lagged price, year by year

\begin{tabular}{|c|c|c|c|c|c|c|c|}
\hline & Mean & $\mathrm{SD}$ & Minimum & Lower quartile & Median & Upper quartile & Maximun \\
\hline \multicolumn{8}{|c|}{ Panel A: Simple model $\frac{\text { feps } s_{t+1}}{P_{t}}=\delta_{1}+\delta_{2} \frac{e_{t}}{P_{t}}+\delta_{3} \frac{b_{t}}{P_{t}}+\delta_{4} \frac{b_{t-1}}{P_{t}}+\varepsilon_{t+1}$} \\
\hline$N$ & 1,734 & 551 & 600 & 1,397 & 1,589 & 2,292 & 2,573 \\
\hline \multirow[t]{2}{*}{$\delta_{1}$} & 0.049 & 0.014 & 0.027 & 0.039 & 0.047 & 0.058 & 0.079 \\
\hline & $(11.97)$ & $(3.80)$ & $(4.56)$ & $(9.58)$ & $(12.28)$ & $(14.08)$ & (19.05) \\
\hline \multirow[t]{2}{*}{$\delta_{2}$} & 0.295 & 0.099 & 0.156 & 0.227 & 0.268 & 0.359 & 0.501 \\
\hline & $(7.73)$ & $(2.32)$ & $(3.03)$ & $(6.73)$ & $(7.95)$ & $(9.03)$ & $(13.50)$ \\
\hline \multirow[t]{2}{*}{$\delta_{3}$} & 0.018 & 0.021 & -0.028 & 0.006 & 0.017 & 0.030 & 0.080 \\
\hline & $(1.68)$ & $(2.00)$ & $(-1.60)$ & $(0.39)$ & $(1.32)$ & $(2.73)$ & $(7.36)$ \\
\hline \multirow[t]{2}{*}{$\delta_{4}$} & 0.013 & 0.018 & -0.034 & 0.000 & 0.012 & 0.021 & 0.060 \\
\hline & $(0.95)$ & $(1.43)$ & $(-3.88)$ & $(0.11)$ & $(0.92)$ & (1.74) & $(3.65)$ \\
\hline$R^{2} \operatorname{adj}(\%)$ & 30.3 & 9.6 & 15.1 & 23.3 & 28.1 & 35.2 & 51.9 \\
\hline \multicolumn{8}{|c|}{ Panel B: Extended model $\frac{f e p s_{t+1}}{P_{t}}=\delta_{1}^{\prime}+\delta_{2}^{\prime} \frac{e_{t}}{P_{t}}+\delta_{3}^{\prime} \frac{b_{t}}{P_{t}}+\delta_{4}^{\prime} \frac{b_{t-1}}{P_{t}}+\delta_{5}^{\prime} \frac{P_{t-1}}{P_{t}}+\varepsilon_{t+1}^{\prime}$} \\
\hline \multirow[t]{2}{*}{$\delta_{1}^{\prime}$} & 0.050 & 0.014 & 0.031 & 0.039 & 0.047 & 0.057 & 0.087 \\
\hline & (11.34) & $(2.45)$ & $(4.77)$ & $(9.66)$ & $(11.21)$ & (13.54) & $(15.20)$ \\
\hline \multirow[t]{2}{*}{$\delta_{2}^{\prime}$} & 0.306 & 0.094 & 0.191 & 0.232 & 0.280 & 0.385 & 0.483 \\
\hline & (11.37) & $(2.80)$ & $(6.88)$ & $(9.22)$ & (11.09) & (12.67) & (19.77) \\
\hline \multirow[t]{2}{*}{$\delta_{3}^{\prime}$} & 0.009 & 0.016 & -0.016 & -0.005 & 0.007 & 0.019 & 0.057 \\
\hline & $(0.68)$ & $(1.27)$ & $(-1.16)$ & $(-0.40)$ & $(0.72)$ & $(1.54)$ & $(4.24)$ \\
\hline \multirow[t]{2}{*}{$\delta_{4}^{\prime}$} & 0.022 & 0.015 & -0.015 & 0.012 & 0.023 & 0.033 & 0.049 \\
\hline & $(1.91)$ & $(1.35)$ & $(-1.11)$ & $(0.94)$ & (1.96) & $(2.77)$ & $(4.75)$ \\
\hline \multirow[t]{2}{*}{$\delta_{5}^{\prime}$} & -0.001 & 0.008 & -0.017 & -0.007 & -0.002 & 0.004 & 0.017 \\
\hline & $(-0.35)$ & $(2.27)$ & $(-6.38)$ & $(-1.50)$ & $(-0.44)$ & $(1.03)$ & $(3.90)$ \\
\hline$R^{2} \operatorname{adj}(\%)$ & 37.9 & 8.7 & 26.5 & 30.6 & 36.3 & 44.2 & 60.4 \\
\hline
\end{tabular}

This table reports the descriptive statistics for the 32 regression coefficients of $\delta_{i}(i=1-4)$ and $\delta_{i}^{\prime}$ ( $i=1-5$ ) based on the 32 annual estimates between 1975 and 2006, together with descriptive statistics of their t-values (in brackets). feps $_{t+1}$ is the median consensus forecasts of earnings at the first month after the corresponding I/B/E/S-reported prior-year earnings announcements; $P_{t}$ and $P_{t-1}$ are the contemporary equity price and lagged equity price respectively; $b_{t}$ and $b_{t-1}$ are the contemporary book value of equity and lagged book value of equity respectively; $e_{t}$ is net income before extraordinary items. $N$ is the annual numbers of observations

Easton and Sommers (2007) argue that analysts' forecasts are overly optimistic and provide yearly estimates of this bias between 1990 and 2003. This optimism biases upward the cost of capital. We can formally establish the relationship between realized returns and the implied cost of equity capital as below. The realized return in our model can be written as

$$
R_{t+1}=\frac{P_{t+1}+d_{t+1}}{P_{t}}=\frac{\alpha_{1} b_{t}+\left(\alpha_{1}+\alpha_{2}\right) e_{t+1}+\vartheta_{t+1}}{P_{t}} .
$$

Hence we have

$$
R_{t+1}=R+\left(\alpha_{1}+\alpha_{2}\right) \frac{e_{t+1}-E\left[e_{t+1}\right]}{P_{t}}+\frac{\vartheta_{t+1}-E\left[\vartheta_{t+1}\right]}{P_{t}} .
$$


Table 3 Implied cost of capital, growth rate, and risk premium, year by year

\begin{tabular}{|c|c|c|c|c|c|c|c|c|c|c|c|}
\hline \multirow[t]{3}{*}{ Years } & \multirow{3}{*}{$\begin{array}{l}\text { Sample } \\
\text { size }\end{array}$} & \multicolumn{5}{|c|}{ Panel A: Simple model } & \multicolumn{5}{|c|}{ Panel B: Extended model } \\
\hline & & \multicolumn{2}{|c|}{ Cost of capital } & \multicolumn{2}{|c|}{ Growth } & \multirow{2}{*}{$\begin{array}{l}\mathrm{RP} \\
\%\end{array}$} & \multicolumn{2}{|c|}{ Cost of capital } & \multicolumn{2}{|c|}{ Growth } & \multirow{2}{*}{$\begin{array}{l}\mathrm{RP} \\
\%\end{array}$} \\
\hline & & $\%$ & $t$ Stat & $\%$ & $t$ Stat & & $\%$ & $t$ Stat & $\%$ & $t$ Stat & \\
\hline 1975 & 600 & 15.18 & 43.57 & 7.61 & 13.97 & 7.40 & 15.22 & 41.53 & 7.65 & 13.23 & 7.44 \\
\hline 1976 & 751 & 15.67 & 30.02 & 5.56 & 7.10 & 8.49 & 15.46 & 22.03 & 5.68 & 7.19 & 8.28 \\
\hline 1977 & 1,048 & 16.83 & 37.35 & 3.99 & 6.04 & 9.84 & 16.86 & 37.22 & 4.19 & 6.07 & 9.87 \\
\hline 1978 & 1,143 & 15.86 & 49.78 & 3.73 & 6.37 & 7.54 & 15.92 & 38.68 & 3.65 & 5.39 & 7.60 \\
\hline 1979 & 1,144 & 15.97 & 55.14 & 3.90 & 7.65 & 6.46 & 15.99 & 52.42 & 3.91 & 6.80 & 6.48 \\
\hline 1980 & 1,170 & 16.16 & 46.81 & 5.78 & 13.16 & 4.71 & 16.38 & 43.78 & 5.03 & 9.61 & 4.93 \\
\hline 1981 & 1,243 & 15.18 & 63.54 & 6.09 & 11.27 & 0.93 & 15.19 & 62.70 & 6.00 & 10.40 & 0.94 \\
\hline 1982 & 1,361 & 14.58 & 60.55 & 4.91 & 10.31 & 1.57 & 14.86 & 62.57 & 5.17 & 10.85 & 1.85 \\
\hline 1983 & 1,409 & 12.56 & 69.94 & 5.57 & 13.36 & 1.77 & 12.31 & 45.99 & 5.78 & 13.40 & 1.52 \\
\hline 1984 & 1,417 & 12.94 & 73.25 & 5.03 & 12.50 & 0.68 & 12.97 & 75.11 & 5.07 & 12.59 & 0.71 \\
\hline 1985 & 1,499 & 11.74 & 59.62 & 4.81 & 10.15 & 1.62 & 11.74 & 59.65 & 4.97 & 10.50 & 1.62 \\
\hline 1986 & 1,473 & 10.06 & 36.42 & 2.61 & 4.65 & 2.76 & 9.96 & 34.51 & 2.93 & 5.16 & 2.66 \\
\hline 1987 & 1,502 & 10.11 & 48.51 & 3.58 & 8.52 & 2.17 & 10.17 & 48.20 & 3.37 & 7.11 & 2.23 \\
\hline 1988 & 1,581 & 11.82 & 55.07 & 4.51 & 8.86 & 3.34 & 11.67 & 50.63 & 4.35 & 8.53 & 3.19 \\
\hline 1989 & 1,567 & 89 & 51.29 & 4.38 & 9.16 & 2.39 & 10.95 & 50.33 & 4.37 & 8.28 & 2.45 \\
\hline 1990 & 1,542 & 11.36 & 61.01 & 3.76 & 8.77 & 2.99 & 10.77 & 48.18 & 2.75 & 5.46 & 2.40 \\
\hline 1991 & 1,597 & 10.38 & 46.08 & 4.15 & 8.76 & 3.01 & 10.42 & 45.41 & 3.84 & 7.43 & 3.05 \\
\hline 1992 & 1,678 & 10.01 & 49.21 & 4.38 & 10.17 & 3.82 & 9.97 & 48 & 4.71 & 10.84 & 3.78 \\
\hline 1993 & 1,848 & 9.36 & 44.59 & 3.78 & 8.94 & 4.22 & 9.36 & 44.74 & 3.92 & 8.62 & 4.22 \\
\hline 1994 & 2,183 & 10.03 & 50.65 & 3.60 & 7.78 & 3.34 & 10.02 & 49.96 & 3.58 & 7.55 & 3.33 \\
\hline 199 & 2,45 & 10.26 & 49. & 4.87 & 11.27 & 3.88 & 0.23 & 48.76 & 4.72 & 9.96 & 3.85 \\
\hline 1996 & 2,523 & 9.43 & 54.20 & 3.76 & 9.95 & 3.25 & 9.43 & 53.06 & 3.68 & 8.91 & 3.25 \\
\hline 1997 & 2,573 & 8.54 & 42.52 & 4.01 & 10.77 & 2.32 & 8.54 & 42.77 & 4.08 & 10.28 & 2.32 \\
\hline 199 & $2,50 \mathrm{C}$ & 8.8 & 41. & 3.5 & 8.05 & 3.7 & 8.71 & 37.36 & 3.34 & 6.81 & $3.5 t$ \\
\hline 199 & 2,330 & 9.68 & 52.90 & 3.92 & 9.61 & 4.13 & 9.38 & 45.55 & 3.34 & 7.14 & 3.83 \\
\hline 2000 & 2,188 & 9.83 & 58.22 & 5.04 & 14.05 & 3.67 & 9.65 & 52.34 & 4.58 & 10.96 & 3.49 \\
\hline 2001 & 2,313 & 8.06 & 38.78 & 3.83 & 8.87 & 3.50 & 8.30 & 41.82 & 4.08 & 9.86 & 3.74 \\
\hline 2002 & 2,305 & 8. & 35.33 & 3.24 & 5.06 & 4.58 & 8.58 & 38.49 & 3.73 & 6.43 & 4.76 \\
\hline 2003 & 2,317 & 8.25 & 35.73 & 3.23 & 6.37 & 5.28 & 8.27 & 35.84 & 3.40 & 6.32 & 5.30 \\
\hline 2004 & 2,287 & 7.47 & 27.62 & 2.08 & 3.83 & 4.04 & 7.29 & 26.07 & 2.45 & 4.36 & 3.86 \\
\hline 2005 & 2,245 & 7.70 & 28.35 & 3.34 & 5.89 & 3.65 & 7.70 & 27.84 & 3.55 & 5.81 & 3.65 \\
\hline 2006 & 1,687 & 7.18 & 22.61 & 2.35 & 3.75 & 2.43 & 7.27 & 22.34 & 2.58 & 3.86 & 2.52 \\
\hline Averag & 1,734 & 11.26 & 47.50 & 4.22 & 8.90 & 3.86 & 11.24 & 44.84 & 4.20 & 8.30 & 3.83 \\
\hline SD & 551 & 2.94 & 12.22 & 1.13 & 2.82 & 2.13 & 2.96 & 11.60 & 1.10 & 2.54 & 2.13 \\
\hline Minin & 600 & 7.18 & 22.61 & 2.08 & 3.75 & 0.68 & 7.27 & 22.03 & 2.45 & 3.86 & 0.71 \\
\hline Quartile- & 1,397 & 9.23 & 38.42 & 3.59 & 6.92 & 2.42 & 9.20 & 38.21 & 3.51 & 6.40 & 2.44 \\
\hline Median & 1,589 & 10.19 & 48.86 & 3.96 & 8.86 & 3.57 & 10.20 & 45.48 & 4.00 & 7.91 & 3.53 \\
\hline Quartile-3 & 2,292 & 13.35 & 55.09 & 4.88 & 10.43 & 4.31 & 13.45 & 50.41 & 4.79 & 10.31 & 4.35 \\
\hline
\end{tabular}


Table 3 continued

\begin{tabular}{|c|c|c|c|c|c|c|c|c|c|c|c|}
\hline \multirow[t]{3}{*}{ Years } & \multirow{3}{*}{$\begin{array}{l}\text { Sample } \\
\text { size }\end{array}$} & \multicolumn{5}{|c|}{ Panel A: Simple model } & \multicolumn{5}{|c|}{ Panel B: Extended model } \\
\hline & & \multicolumn{2}{|c|}{ Cost of capital } & \multicolumn{2}{|c|}{ Growth } & \multirow{2}{*}{$\begin{array}{l}\mathrm{RP} \\
\%\end{array}$} & \multicolumn{2}{|c|}{ Cost of capital } & \multicolumn{2}{|c|}{ Growth } & \multirow{2}{*}{$\begin{array}{l}\mathrm{RP} \\
\%\end{array}$} \\
\hline & & $\%$ & $t$ Stat & $\%$ & $t$ Stat & & $\%$ & $t$ Stat & $\%$ & $t$ Stat & \\
\hline Maximum & 2,573 & 16.83 & 73.25 & 7.61 & 14.05 & 9.84 & 16.86 & 75.11 & 7.65 & 13.40 & 9.87 \\
\hline
\end{tabular}

This table reports the implied cost of capital, growth rates, and risk premia computed annually

Panel A reports results from using the simple model, Eq. (10)

$$
\begin{aligned}
& \frac{f e p s_{t+1}}{P_{t}}=\delta_{1}+\delta_{2} \frac{e_{t}}{P_{t}}+\delta_{3} \frac{b_{t}}{P_{t}}+\delta_{4} \frac{b_{t-1}}{P_{t}}+\varepsilon_{t+1}, \text { and } \\
& g=\frac{\left(1+\delta_{2}+\delta_{3}\right)+\sqrt{\left(1+\delta_{2}+\delta_{3}\right)^{2}-4\left(\delta_{2}-\delta_{4}\right)}}{2}-1, \\
& R-1=(1+g)\left(1+\frac{\delta_{1}}{1+g-\delta_{2}}\right)-1
\end{aligned}
$$

Panel B reports results from using the extended model, Eq. (11)

$\frac{f e p s_{t+1}}{P_{t}}=\delta_{1}^{\prime}+\delta_{2}^{\prime} \frac{e_{t}}{P_{t}}+\delta_{3}^{\prime} \frac{b_{t}}{P_{t}}+\delta_{4}^{\prime} \frac{b_{t-1}}{P_{t}}+\delta_{5}^{\prime} \frac{P_{t-1}}{P_{t}}+\varepsilon_{t+1}^{\prime}$, and

$g=\frac{1+\delta_{2}^{\prime}+\delta_{3}^{\prime}-\delta_{5}^{\prime}+\sqrt{\left(1+\delta_{2}^{\prime}+\delta_{3}^{\prime}-\delta_{5}^{\prime}\right)^{2}-4\left(\delta_{2}^{\prime}-\delta_{4}^{\prime}-\delta_{5}^{\prime}\right)}}{2}-1$,

$R-1=(1+g)\left(1+\frac{\delta_{1}^{\prime}+\delta_{5}^{\prime}}{1+g-\delta_{2}^{\prime}}\right)-1$

The risk premium (RP) is calculated relative to the yield on a 5-year US government bond. feps $s_{t+1}$ is the median consensus forecast of earnings at the first month after the corresponding I/B/E/S-reported prioryear earnings announcements; $P_{t}$ and $P_{t-1}$ are the contemporary equity price and lagged equity price respectively; $b_{t}$ and $b_{t-1}$ are the contemporary book value of equity and lagged book value of equity respectively; $e_{t}$ is the net income before extraordinary items

The realized return can be decomposed as the implied cost of capital (expected) component, earnings shocks, and other shocks. This has important implications since, if the information surprise in either of these components is correlated with the expected return, then simple regressions of realized returns on expected return proxies will yield spurious inferences due to correlated omitted variables. ${ }^{21}$

In our analysis, we use 1-year-ahead earnings forecasts, feps $s_{t+1}$, to proxy $E\left[e_{t+1}\right]$; applying Eqs. (2) and (7) we get:

$$
R_{t+1}=R+\left(\alpha_{1}+\alpha_{2}\right) \frac{e_{t+1}-f e p s_{t+1}}{P_{t}}+\frac{\varepsilon_{v t+1}}{P_{t}} .
$$

If $f e p s_{t+1}$ is a perfect forecast, then the expected return should be equal to the implied cost of capital since $\varepsilon_{v t+1}$ has zero mean by assumption. Even in this case, other information shocks can have substantial variance (McInnis 2010). We may not be able to observe the relation between the implied cost of capital and risk factors, including beta and size. On the other hand, if $e_{t+1}-f e p s_{t+1}$ is not mean zero over the sample period and $f e p s_{t+1}$ is a biased proxy for $E\left[e_{t+1}\right]$, then the implied cost of capital will be biased proxy for expected returns. If $f e p s_{t+1}$ is overstated relative to $e_{t+1}$, then $R$ will be overestimated on average. This should reflect the effect of

\footnotetext{
$\overline{21}$ Elton (1999) argues information surprises cause realized returns to be a biased, noisy measure of expected returns.
} 


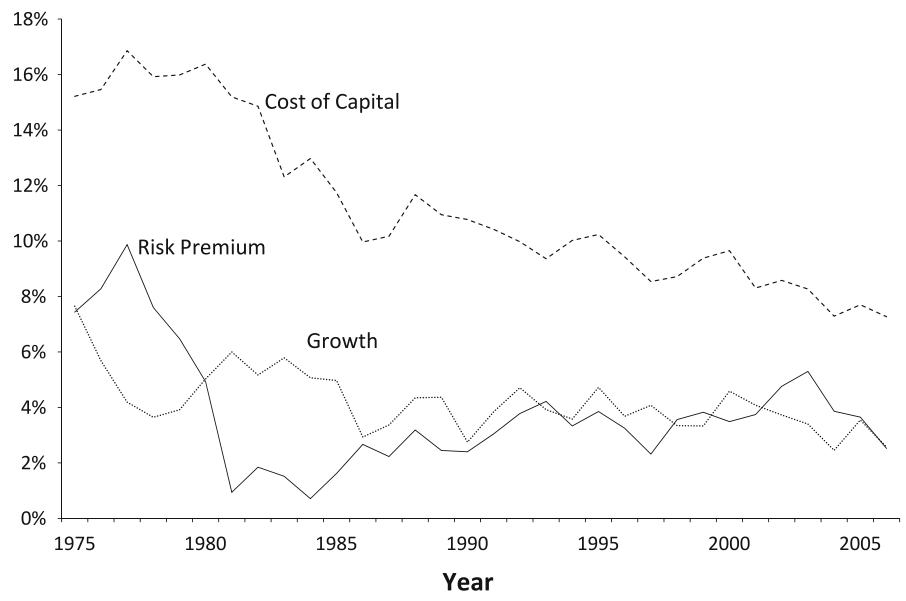

Fig. 1 The relation between estimates of the cost of capital, growth and risk premium. This figure shows the trends of risk premium and growth rate over 1975-2006 based on our extended model. Risk premium is equal to the difference between the implied cost of capital and 5-year US government bond yields. Growth rate is the expected equilibrium growth rate implied in the analysts' forecasted earnings

analysts' optimism on estimates of the expected rate of return implied by earnings forecasts.

It is relatively easy to estimate the impact of this bias on the assumption that its main impact is on the intercept term $\delta_{1}^{\prime}$ in Eq. (11). When we adjust the values in our Table 3, using the data published in Table 1 of Easton and Sommers (2007) and make new estimates based on Eq. (9), we find that the bias affects our estimates of the cost of capital and the risk premium but not growth. The net impact of this bias is an average reduction in the cost of capital and risk premium of just $0.59 \%$. The impact of this bias is less than that reported using other models as is evidenced in Nekrasov and Ogneva (2011).

Similarly, we find that our estimates of the mean growth rates in the simple and the extended model differ by only $0.02 \%$, suggesting a long run growth rate of just over $4 \%$. We also note a downward trend in the cost of capital, with the average falling from $15.1 \%$ between 1975 and 1984 to $10.6 \%$ between 1985 and 1994 and finally to $8.6 \%$ between 1995 and 2006 . Figure 1 illustrates the downward trend in cost of capital and compares this with our more stable estimates of the risk premium and long-run growth.

\subsubsection{Analysis on an industry basis}

We repeat the above analysis on an industry-by-industry basis to estimate the growth rate and the rate of return on equity investment. We employ the panel data methodology of Gow et al. (2010) to estimate two-way cluster-robust standard errors to correct both time-series and cross-sectional correlations. Our sample size varies across 48 industries, from a low of 36 firm-years in the tobacco products industry (smoke) to a high of 6,287 firm-years in the banking industry. The average number of observation within each industry is 1,156 . Regressing one-period-ahead 
Table 4 The descriptive statistics for regressing forecasted earnings on price, earnings, book value, and lagged book value, industry by industry

\begin{tabular}{|c|c|c|c|c|c|c|c|}
\hline & Mean & SD & Minimum & Lower quartile & Median & Upper quartile & Maximum \\
\hline \multicolumn{8}{|c|}{ Panel A: Simple model $\frac{\text { feps }}{P_{t}}=\delta_{1}+\delta_{2} \frac{e_{t}}{P_{t}}+\delta_{3} \frac{b_{t}}{P_{t}}+\delta_{4} \frac{b_{t-1}}{P_{t}}+\varepsilon_{t+1}$} \\
\hline$N$ & 1,156 & 1,165 & 36 & 260 & 888 & 1,479 & 6,287 \\
\hline \multirow[t]{2}{*}{$\delta_{1}$} & 0.047 & 0.018 & 0.005 & 0.038 & 0.044 & 0.056 & 0.107 \\
\hline & $(6.25)$ & $(2.86)$ & $(0.53)$ & $(4.42)$ & (6.06) & $(8.61)$ & (12.02) \\
\hline \multirow[t]{2}{*}{$\delta_{2}$} & 0.273 & 0.102 & 0.070 & 0.211 & 0.267 & 0.325 & 0.644 \\
\hline & $(5.12)$ & $(2.93)$ & $(0.64)$ & $(2.93)$ & $(5.24)$ & (6.19) & (14.38) \\
\hline \multirow[t]{2}{*}{$\delta_{3}$} & 0.020 & 0.030 & -0.066 & 0.003 & 0.022 & 0.034 & 0.096 \\
\hline & $(1.40)$ & $(1.77)$ & $(-1.52)$ & $(0.11)$ & (1.16) & $(2.11)$ & $(6.28)$ \\
\hline \multirow[t]{2}{*}{$\delta_{4}$} & 0.015 & 0.030 & -0.077 & -0.002 & 0.013 & 0.036 & 0.121 \\
\hline & $(0.88)$ & (1.73) & $(-2.19)$ & $(-0.47)$ & $(0.85)$ & $(1.72)$ & (5.89) \\
\hline$R^{2}$ adj $(\%)$ & 33.0 & 14.7 & -1.6 & 25.6 & 33.8 & 40.4 & 71.8 \\
\hline \multicolumn{8}{|c|}{ Panel B: Extended model $\frac{\text { fep } s_{t+1}}{P_{t}}=\delta_{1}^{\prime}+\delta_{2}^{\prime} \frac{e_{t}}{P_{t}}+\delta_{3}^{\prime} \frac{b_{t}}{P_{t}}+\delta_{4}^{\prime} \frac{b_{t-1}}{P_{t}}+\delta_{5}^{\prime} \frac{P_{t-1}}{P_{t}}+\varepsilon_{t+1}^{\prime}$} \\
\hline \multirow[t]{2}{*}{$\delta_{1}^{\prime}$} & 0.047 & 0.017 & 0.009 & 0.037 & 0.048 & 0.057 & 0.103 \\
\hline & $(6.94)$ & $(3.21)$ & $(1.51)$ & $(4.37)$ & (7.13) & $(9.34)$ & (13.91) \\
\hline \multirow[t]{2}{*}{$\delta_{2}^{\prime}$} & 0.287 & 0.063 & 0.167 & 0.248 & 0.282 & 0.317 & 0.455 \\
\hline & $(6.99)$ & $(3.31)$ & (1.73) & (4.69) & $(7.00)$ & $(8.57)$ & (15.71) \\
\hline \multirow[t]{2}{*}{$\delta_{3}^{\prime}$} & 0.010 & 0.026 & -0.092 & 0.001 & 0.010 & 0.022 & 0.068 \\
\hline & $(0.82)$ & $(1.31)$ & $(-2.36)$ & $(0.09)$ & $(0.62)$ & $(1.45)$ & $(4.25)$ \\
\hline \multirow[t]{2}{*}{$\delta_{4}^{\prime}$} & 0.022 & 0.028 & -0.047 & 0.007 & 0.024 & 0.035 & 0.110 \\
\hline & $(1.59)$ & $(1.91)$ & $(-3.53)$ & $(0.27)$ & $(1.52)$ & $(2.65)$ & (7.16) \\
\hline \multirow[t]{2}{*}{$\delta_{5}^{\prime}$} & 0.000 & 0.009 & -0.026 & -0.003 & 0.000 & 0.005 & 0.027 \\
\hline & $(0.12)$ & $(1.30)$ & $(-2.17)$ & $(-0.57)$ & $(-0.02)$ & $(0.59)$ & (3.39) \\
\hline$R^{2} \operatorname{adj}(\%)$ & 39.8 & 11.8 & 7.6 & 31.7 & 39.5 & 44.2 & 73.3 \\
\hline
\end{tabular}

This table reports the descriptive statistics for the 48 regression coefficients of $\delta_{i}(i=1-4)$ and $\delta_{i}^{\prime}(i=$ 1-5) based on the 48 industry groups over the period 1975-2006, together with descriptive statistics of their $t$ values (in brackets). Industry classification is per Fama and French (1997). feps $s_{t+1}$ is the median consensus forecast of earnings at the first month after the corresponding I/B/E/S-reported prior-year earnings announcements; $P_{t}$ and $P_{t-1}$ are the contemporary equity price and lagged equity price respectively; $b_{t}$ and $b_{t-1}$ are the contemporary book value of equity and lagged book value of equity respectively; $e_{t}$ is the net income before extraordinary items. $N$ is the numbers of observations. Two-way cluster-robust standard errors are used to correct for both cross-sectional and time-series dependence

forecasted earnings on earnings, book value, and lagged book value per share, all deflated by prices for each industry based on Eqs. (10) and (11), we obtain the regression coefficients in the two models and report summary statistics in Table 4.

In the case of the simple model, again we observe that the dominant explanatory variables are price, $\left(\delta_{1}\right)$, and earnings, $\left(\delta_{2}\right)$. All 48 parameter estimates of the coefficients of price and earnings are positive. ${ }^{22}$ The coefficients of book value and lagged book value are positive but not statistically significant. When we examine

\footnotetext{
${ }^{22}$ We use the procedure nlcom in Stata to determine the t-statistics for functions of the regression parameters.
} 
the extended model, we again find that the dominant explanatory variables are associated with price $\left(\delta_{1}^{\prime}\right)$ and earnings $\left(\delta_{2}^{\prime}\right)$. The coefficients of (lagged) book values and lagged price are positive but not statistically significant.

Table 5 details the cost of capital, growth rates, and risk premium of the individual industries over the sample period, and Table 6, Panels A and B, provide summary statistics. In Panel 6A, we observe an industry mean cost of capital of $10.96 \%$ and an industry mean growth rate of $4.74 \%$ for the simple model. Although the industry mean cost of capital for the extended model in Panel 6B is slightly less than that for the simple model at $10.79 \%$, it is not significantly so. However, the industry mean growth rate for the extended model in Panel 6B is $4.21 \%$, virtually identical to the mean estimated on a year-by-year basis. Two industries: soda and beer have negative growth rates for both the simple and the extended models, and the coal industry has a negative growth rate for the simple model, perhaps reflecting changing consumer habits in the light of health and environmental concerns. The risk premia for a few industries are negative in the simple model. However only the estimate of the risk premium for the gold industry remains significantly negative in the extended model. In Table 6 , Panel $\mathrm{B}$, we see that the average risk premium is only $3.1 \%$, and the median risk premium is $3.5 \%$. These estimates are slightly lower than those made in most previous studies. However, our sample size is greater than that used in previous studies. In contrast to Easton et al. (2002), Gebhardt et al. (2001), Gode and Mohanram (2003), we require only 1-year-ahead forecasts, which reduces problems caused by survivorship bias and we also include firms with negative earnings forecasts. We repeat our analysis by dropping all negative forecasted earnings from our sample. The results are shown in Table 6, Panels C and D. We note that, although the average cost of capital is largely unaffected and remains at around $11 \%$ for the extended model, the average risk premium is increased by about $0.4 \%$ to $3.51 \%$, a value that is close to our year-by-year estimates of the average risk premium, whether we use the restricted set or the full set. ${ }^{23}$ The average growth rate increases by about $0.2 \%$. In the specific case of the pharmaceutical industry, when we consider only positive earnings forecasts, the sample size falls from 1,669 to 945, and we find that the cost of capital increases to $10.8 \%$, giving a positive risk premium of $4.2 \%{ }^{24}$ It may seem perverse that excluding firms with predicted negative earnings increases the average implied cost of capital. But recall that the implied cost of capital is a misnomer, even though the phrase is standard in this literature. What we are actually computing is the implied rate of return based on analysts' forecasts of earnings. In this context, when we exclude firms with predicted negative earnings, analysts' "expectations" of growth increase. While the results are to some extent sensitive to our choice of models, they are considerably more sensitive to the data set used.

\footnotetext{
${ }^{23}$ The average quoted is a simple arithmetic average over years or industries and is not weighted by the number of observations.

${ }^{24}$ In the case of the gold industry, when we consider only positive earnings forecasts, the sample size falls from 188 to 147 but we still find that a negative risk premium of $1.6 \%$. In fact, the gold industry is the only industry with negative risk premium when we restrict our sample to only those firms with positive earnings forecasts.
} 
Table 5 Implied cost of capital, growth rate, and valuation parameters, industry by industry

\begin{tabular}{|c|c|c|c|c|c|c|c|c|c|c|c|}
\hline \multirow[t]{3}{*}{ Industry } & \multirow[t]{3}{*}{$N$} & \multicolumn{5}{|c|}{ Panel A: Simple model } & \multicolumn{5}{|c|}{ Panel B: Extended model } \\
\hline & & \multicolumn{2}{|c|}{ Cost of capital } & \multicolumn{2}{|c|}{ Growth } & \multirow{2}{*}{$\begin{array}{l}\mathrm{RP} \\
\%\end{array}$} & \multicolumn{2}{|c|}{ Cost of capital } & \multicolumn{2}{|c|}{ Growth } & \multirow{2}{*}{$\begin{array}{l}\mathrm{RP} \\
\%\end{array}$} \\
\hline & & $\%$ & $t$ Stat & $\%$ & $t$ Stat & & $\%$ & $t$ Stat & $\%$ & $t$ Stat & \\
\hline Agric & 140 & 11.93 & 8.97 & 7.47 & 4.56 & 2.25 & 11.54 & 8.09 & 6.33 & 4.95 & 2.52 \\
\hline Food & 1,103 & 11.69 & 43.36 & 5.81 & 6.22 & 4.03 & 11.35 & 54.35 & 5.54 & 8.06 & 3.63 \\
\hline Soda & 116 & 6.31 & 23.65 & -3.25 & -1.32 & 0.15 & 6.47 & 24.23 & -2.75 & -1.34 & 0.31 \\
\hline Beer & 128 & 7.06 & 27.97 & -1.84 & -1.16 & -0.24 & 6.58 & 27.35 & -1.50 & -1.09 & -0.44 \\
\hline Smoke & 36 & 15.71 & 56.34 & 3.80 & 1.82 & 6.67 & 14.83 & 9.99 & 4.27 & 3.32 & 7.16 \\
\hline Toys & 264 & 11.94 & 18.72 & 4.28 & 2.78 & 4.74 & 11.41 & 23.71 & 3.87 & 2.97 & 3.92 \\
\hline Fun & 715 & 9.79 & 24.23 & 1.50 & 1.22 & 2.35 & 9.65 & 44.02 & 1.35 & 1.41 & 2.29 \\
\hline Books & 712 & 10.89 & 16.27 & 4.73 & 1.87 & 3.73 & 10.07 & 24.19 & 3.42 & 1.74 & 2.90 \\
\hline Hshld & 1,195 & 12.49 & 38.99 & 5.39 & 5.34 & 4.74 & 12.29 & 63.77 & 4.56 & 6.06 & 4.49 \\
\hline Clths & 872 & 11.51 & 44.09 & 4.30 & 4.67 & 3.93 & 11.51 & 76.02 & 4.64 & 8.02 & 3.98 \\
\hline Hlth & 737 & 9.54 & 18.54 & 4.10 & 3.64 & 3.16 & 9.24 & 20.64 & 3.53 & 3.40 & 2.82 \\
\hline MedEq & 1,368 & 9.82 & 13.09 & 5.97 & 2.67 & 0.90 & 8.75 & 16.19 & 4.30 & 3.67 & 0.80 \\
\hline Drugs & 1,669 & 7.75 & 1.97 & 6.53 & 2.33 & -3.94 & 9.07 & 10.54 & 7.23 & 5.28 & -0.75 \\
\hline Chems & 1,296 & 12.52 & 25.70 & 6.61 & 3.54 & 4.86 & 11.82 & 36.82 & 5.69 & 5.31 & 4.15 \\
\hline Rubbr & 527 & 11.92 & 23.47 & 5.40 & 6.04 & 3.98 & 11.56 & 29.73 & 4.68 & 6.10 & 3.62 \\
\hline Txtls & 572 & 12.76 & 33.25 & 4.81 & 7.67 & 4.38 & 12.83 & 42.00 & 4.12 & 6.68 & 4.50 \\
\hline BldMt & 1,447 & 12.80 & 64.34 & 7.04 & 5.57 & 4.82 & 12.35 & 84.30 & 5.16 & 7.99 & 4.35 \\
\hline Cnstr & 657 & 12.75 & 53.33 & 5.20 & 4.63 & 5.16 & 12.21 & 54.61 & 4.25 & 5.49 & 4.73 \\
\hline Steel & 1,164 & 11.86 & 40.59 & 2.68 & 2.80 & 4.09 & 11.59 & 64.74 & 2.84 & 4.14 & 3.86 \\
\hline $\mathrm{FabPr}$ & 246 & 11.56 & 28.56 & 3.12 & 2.68 & 3.90 & 11.82 & 25.24 & 3.12 & 2.32 & 4.06 \\
\hline Mach & 2,277 & 11.30 & 49.24 & 5.12 & 6.17 & 3.19 & 11.22 & 49.10 & 4.92 & 7.71 & 3.24 \\
\hline $\mathrm{ElcEq}$ & 764 & 12.12 & 13.99 & 5.13 & 2.52 & 3.17 & 12.20 & 16.97 & 5.48 & 3.36 & 3.33 \\
\hline Other & 222 & 12.67 & 19.87 & 9.92 & 5.77 & 5.86 & 12.31 & 33.39 & 7.13 & 7.61 & 4.48 \\
\hline Autos & 1,190 & 12.85 & 45.66 & 7.14 & 4.43 & 4.85 & 11.91 & 58.11 & 5.05 & 7.77 & 4.16 \\
\hline Aero & 394 & 11.91 & 65.20 & 4.17 & 2.68 & 4.06 & 11.85 & 103.63 & 3.63 & 2.74 & 3.61 \\
\hline Ships & 216 & 13.54 & 47.56 & 10.29 & 8.99 & 5.36 & 13.26 & 42.87 & 8.86 & 15.25 & 4.99 \\
\hline Guns & 57 & 12.89 & 34.43 & 8.13 & 3.37 & 5.99 & 12.77 & 35.90 & 7.47 & 3.48 & 5.60 \\
\hline Gold & 188 & 5.69 & 4.14 & 4.91 & 2.30 & -1.37 & 4.95 & 3.75 & 2.29 & 2.12 & -1.93 \\
\hline Mines & 175 & 14.54 & 6.31 & 5.93 & 1.35 & 5.74 & 12.78 & 10.91 & 5.34 & 2.13 & 4.23 \\
\hline Coal & 84 & 8.36 & 11.06 & -0.88 & -0.72 & -0.10 & 9.51 & 11.63 & 0.17 & 0.19 & 1.18 \\
\hline Oil & 2,075 & 10.07 & 28.49 & 3.69 & 3.18 & 1.94 & 9.94 & 37.53 & 3.91 & 5.45 & 1.90 \\
\hline Util & 2,864 & 11.37 & 59.87 & 7.21 & 5.75 & 3.97 & 11.03 & 82.15 & 6.36 & 7.04 & 3.53 \\
\hline Telcm & 975 & 6.95 & 9.27 & 1.23 & 1.00 & -0.37 & 7.15 & 20.02 & 0.87 & 1.17 & -0.14 \\
\hline PerSv & 461 & 9.39 & 22.56 & 4.74 & 4.55 & 2.34 & 9.22 & 17.93 & 4.77 & 4.00 & 2.25 \\
\hline BusSv & 3,677 & 9.55 & 19.00 & 4.17 & 3.65 & 1.72 & 10.01 & 38.10 & 4.81 & 8.23 & 2.22 \\
\hline Comps & 1,864 & 9.74 & 7.32 & 6.19 & 6.11 & 0.94 & 10.79 & 27.11 & 5.42 & 7.91 & 2.57 \\
\hline Chips & 2,831 & 9.94 & 25.30 & 4.24 & 3.29 & 2.11 & 10.45 & 39.89 & 5.15 & 6.84 & 2.63 \\
\hline LabEq & 1,366 & 10.04 & 17.34 & 4.68 & 5.11 & 1.69 & 10.41 & 27.51 & 5.23 & 6.19 & 2.24 \\
\hline Paper & 1,153 & 11.51 & 71.06 & 3.36 & 3.24 & 3.99 & 11.37 & 70.64 & 3.47 & 3.65 & 3.89 \\
\hline
\end{tabular}


Table 5 continued

\begin{tabular}{|c|c|c|c|c|c|c|c|c|c|c|c|}
\hline \multirow[t]{3}{*}{ Industry } & \multirow[t]{3}{*}{$N$} & \multicolumn{5}{|c|}{ Panel A: Simple model } & \multicolumn{5}{|c|}{ Panel B: Extended model } \\
\hline & & \multicolumn{2}{|c|}{ Cost of capital } & \multicolumn{2}{|c|}{ Growth } & \multirow{2}{*}{$\begin{array}{l}\mathrm{RP} \\
\%\end{array}$} & \multicolumn{2}{|c|}{ Cost of capital } & \multicolumn{2}{|c|}{ Growth } & \multirow{2}{*}{$\begin{array}{l}\mathrm{RP} \\
\%\end{array}$} \\
\hline & & $\%$ & $t$ Stat & $\%$ & $t$ Stat & & $\%$ & $t$ Stat & $\%$ & $t$ Stat & \\
\hline Boxes & 278 & 11.60 & 35.37 & 3.54 & 1.15 & 3.57 & 11.29 & 37.59 & 3.83 & 2.50 & 3.57 \\
\hline Trans & 1,377 & 11.37 & 51.03 & 5.80 & 3.63 & 3.91 & 10.87 & 60.22 & 3.84 & 6.69 & 3.48 \\
\hline Whlsl & 1,929 & 11.27 & 54.45 & 5.46 & 6.34 & 3.79 & 11.00 & 74.80 & 4.49 & 8.05 & 3.50 \\
\hline Rtail & 3,196 & 11.62 & 75.64 & 5.52 & 6.80 & 4.06 & 10.97 & 135.22 & 4.28 & 8.47 & 3.18 \\
\hline Meals & 904 & 10.27 & 18.07 & 3.79 & 2.75 & 2.96 & 10.41 & 22.90 & 3.37 & 2.75 & 2.73 \\
\hline Banks & 6,287 & 12.05 & 107.44 & 7.61 & 8.16 & 5.68 & 12.03 & 226.58 & 7.16 & 11.47 & 5.58 \\
\hline Insur & 1,941 & 11.34 & 114.80 & 4.53 & 7.20 & 4.74 & 11.28 & 151.14 & 3.77 & 6.50 & 4.62 \\
\hline RlEst & 196 & 9.94 & 12.23 & 3.10 & 2.46 & 1.51 & 10.20 & 22.43 & 2.00 & 1.48 & 1.62 \\
\hline Fin & 1,576 & 9.77 & 18.10 & 5.15 & 3.29 & 4.01 & 9.69 & 44.80 & 4.42 & 5.21 & 3.48 \\
\hline
\end{tabular}

This table reports the implied cost of capital, growth rates, and risk premia computed on an industry basis. Industry classification is per Fama and French (1997)

Panel A reports results from using the simple model, Eq. (10)

$\frac{\text { feps }_{t+1}}{P_{t}}=\delta_{1}+\delta_{2} \frac{e_{t}}{P_{t}}+\delta_{3} \frac{b_{t}}{P_{t}}+\delta_{4} \frac{b_{t-1}}{P_{t}}+\varepsilon_{t+1}$, and

$g=\frac{\left(1+\delta_{2}+\delta_{3}\right)+\sqrt{\left(1+\delta_{2}+\delta_{3}\right)^{2}-4\left(\delta_{2}-\delta_{4}\right)}}{2}-1$,

$R-1=(1+g)\left(1+\frac{\delta_{1}}{1+g-\delta_{2}}\right)-1$

Panel B reports results from using the extended model, Eq. (11)

$\frac{f e p s_{t+1}}{P_{t}}=\delta_{1}^{\prime}+\delta_{2}^{\prime} \frac{e_{t}}{P_{t}}+\delta_{3}^{\prime} \frac{b_{t}}{P_{t}}+\delta_{4}^{\prime} \frac{b_{t-1}}{P_{t}}+\delta_{5}^{\prime} \frac{P_{t-1}}{P_{t}}+\varepsilon_{t+1}^{\prime}$, and

$g=\frac{1+\delta_{2}^{\prime}+\delta_{3}^{\prime}-\delta_{5}^{\prime}+\sqrt{\left(1+\delta_{2}^{\prime}+\delta_{3}^{\prime}-\delta_{5}^{\prime}\right)^{2}-4\left(\delta_{2}^{\prime}-\delta_{4}^{\prime}-\delta_{5}^{\prime}\right)}}{2}-1$,

$R-1=(1+g)\left(1+\frac{\delta_{1}^{\prime}+\delta_{5}^{\prime}}{1+g-\delta_{2}^{\prime}}\right)-1$

The risk premium (RP) is calculated relative to the yield on a 5-year US government bond. $f_{e p s_{t+1}}$ is the median consensus forecast of earnings at the first month after the corresponding I/B/E/S-reported prioryear earnings announcement; $P_{t}$ and $P_{t-1}$ are the contemporary equity price and lagged equity price respectively; $b_{t}$ and $b_{t-1}$ are the contemporary book value of equity and lagged book value of equity respectively; $e_{t}$ is the net income before extraordinary items. $N$ is the numbers of observations. Two-way cluster-robust standard errors are used to correct for both cross-sectional and time-series dependence

Clearly we need some external validation of our estimates. Unfortunately the usual method of attempting to relate to accounting risk proxies is not open to us. We can recast of our model (6) in the form of Eq. (14):

$$
R=(1+g)+\left(\alpha_{1}+\alpha_{2}\right) \frac{E\left[e_{t+1}\right]}{P_{t}}-(1+g) \alpha_{2} \frac{e_{t}}{P_{t}}-g \alpha_{1} \frac{b_{t}}{P_{t}}-(1+g)\left(\alpha_{1}-1\right) \frac{d_{t}}{P_{t}} .
$$

Here we see that the most common accounting risk proxies are effectively inputs into our estimation procedures. ${ }^{25}$ This has important implications for exploring any

\footnotetext{
${ }^{25}$ We tried other commonly used risk proxies such as beta and size but the nonhomogeneity of the data in the sector produced insignificant results, though Easton (2009) argues that "given that the theoretical
} 
relation between the estimates of implied cost of capital and accounting-based risk proxies and growth. Caution must be taken if one adds an explanatory variable into regressions of the implied rate of return estimated from an accounting-based valuation model. Botosan and Plumlee (2005) note this spurious effect: when they add expected earnings growth as an additional explanatory variable in their regression, the R-squared increases from $23 \%$ to nearly $74 \%$. Easton (2009) concludes that "in light of these spurious influences, which will differ across methods of estimating the expected rate of return, it is not clear what can be learned from regressions of these estimates on risk proxies."

\subsection{Comparison of our results with prior literature}

Notwithstanding the remarks in the last paragraph about comparability, we compare our results with earlier studies that have used the same industry classification. The results are reported in Panel A of Table 7, which shows the correlation coefficients and summary statistics of a comparison with Fama and French (1997) based on the three-factor model and those generated by Gebhardt et al. (2001) using a residual income model on risk premia.

Although the industry classification is common, the sample sizes vary both within industries and over time. Our estimates are based on the period of 1975-2006. In contrast, that of Fama and French covers the period of 1963-1994, while the results reported by Gebhardt et al. (2001) cover the shorter period of 1979-1995. Their annual average sample size is on the order of 1,150, while ours is about 1,734. Although the correlation coefficients of 0.42 and 0.335 between our estimate and the other two over the common period of their estimation are just about significant at a 1 and $5 \%$ levels respectively, there remains substantial unexplained variability between the various estimates.

Rather more authors have reported annual risk premia over a number of years, and Panel B summarizes a statistical comparison of the estimates in this paper compared with those made by Fama and French (1997), Claus and Thomas (2001), Gebhardt et al. (2001), Easton et al. (2002), and Gode and Mohanram (2003). We observe that, over the common period, ours is the lowest estimate. However, bear in mind that, with the exception of Fama and French (1997), we have also the largest sample because we require only 1-year-ahead forecasts, and we have included rather more loss-making firms and firms with limited number of forecasts. We again note in this context that the risk premium reported by Gode and Mohanram (2003) falls to just over $1 \%$, when they use a residual income model and include firms with negative time $t+1$ and $t+2$ periods forecasted earnings, feps $s_{1}, f e p s_{2}<0$, to estimate the industry median return on equity.

We also compute the correlation coefficients between the various year-by-year estimates. In general, we see that the highest and most significant correlation between our estimates and those of Gebhardt et al. (2001) and Easton et al. (2002).

Footnote 25 continued

models are questionable, it is illogical to use measures based on these models (for example, CAPM beta) to evaluate the validity of an accounting-based proxy." 


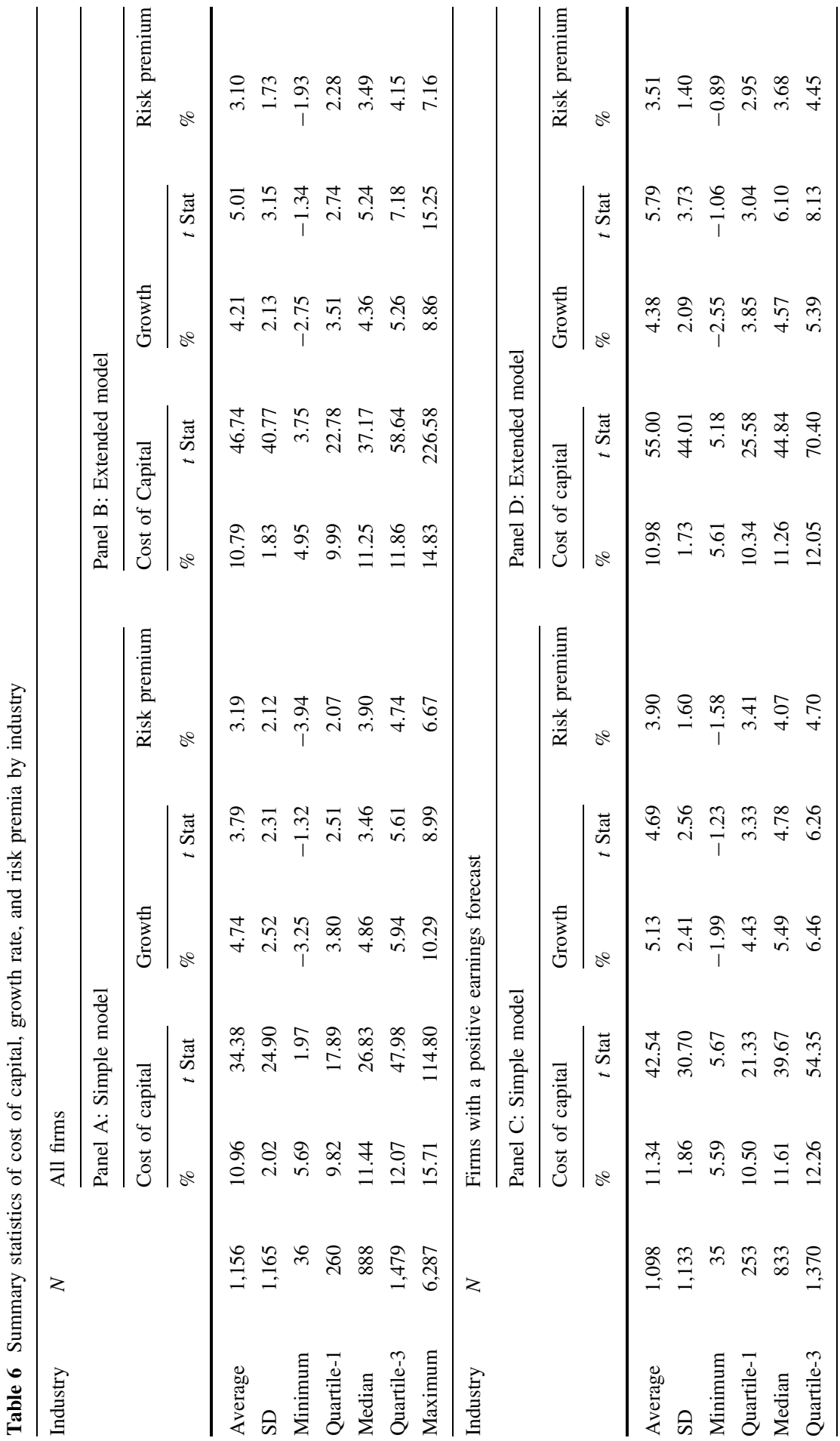




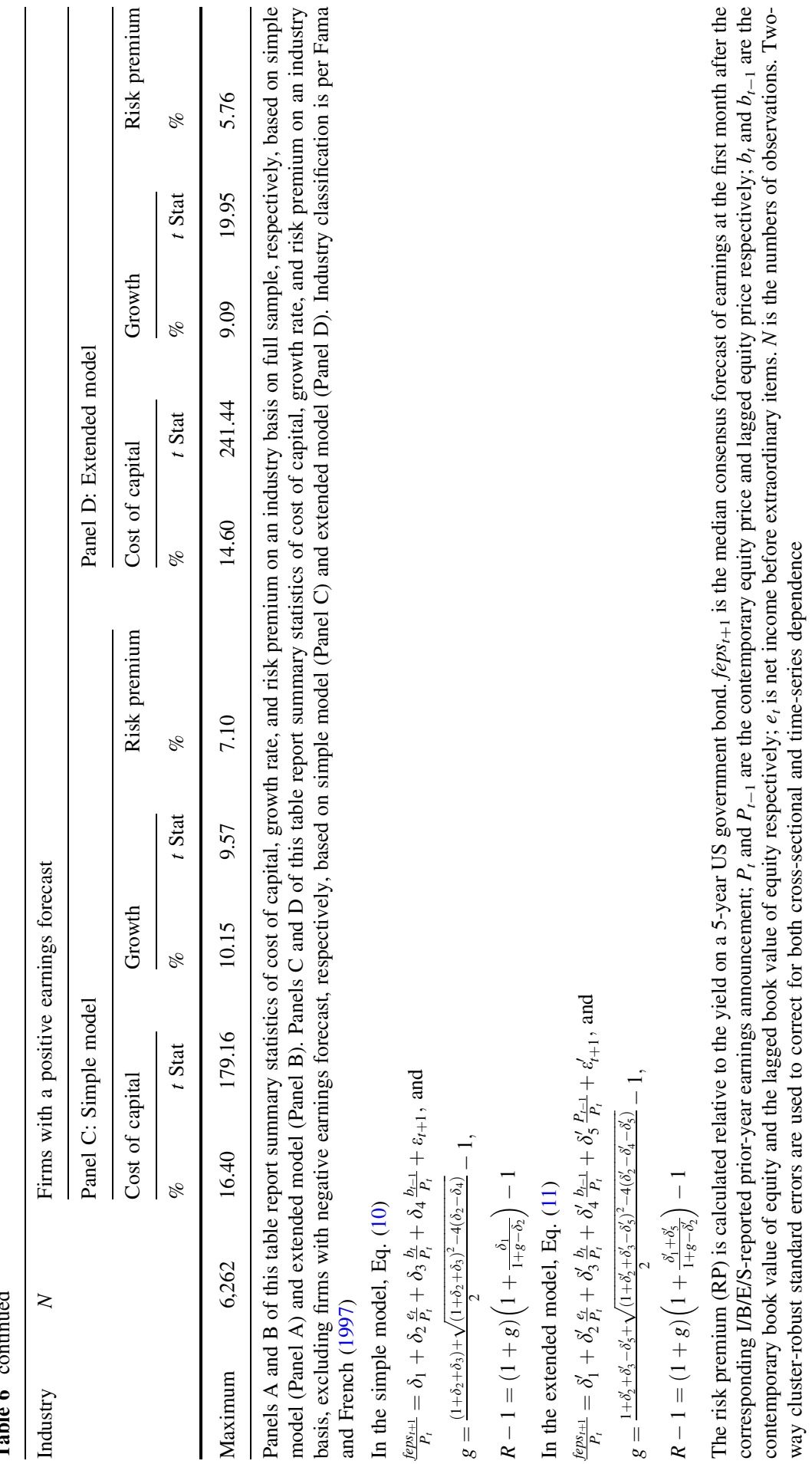


Table 7 Correlation and statistics of risk premia estimated in this paper and prior studies

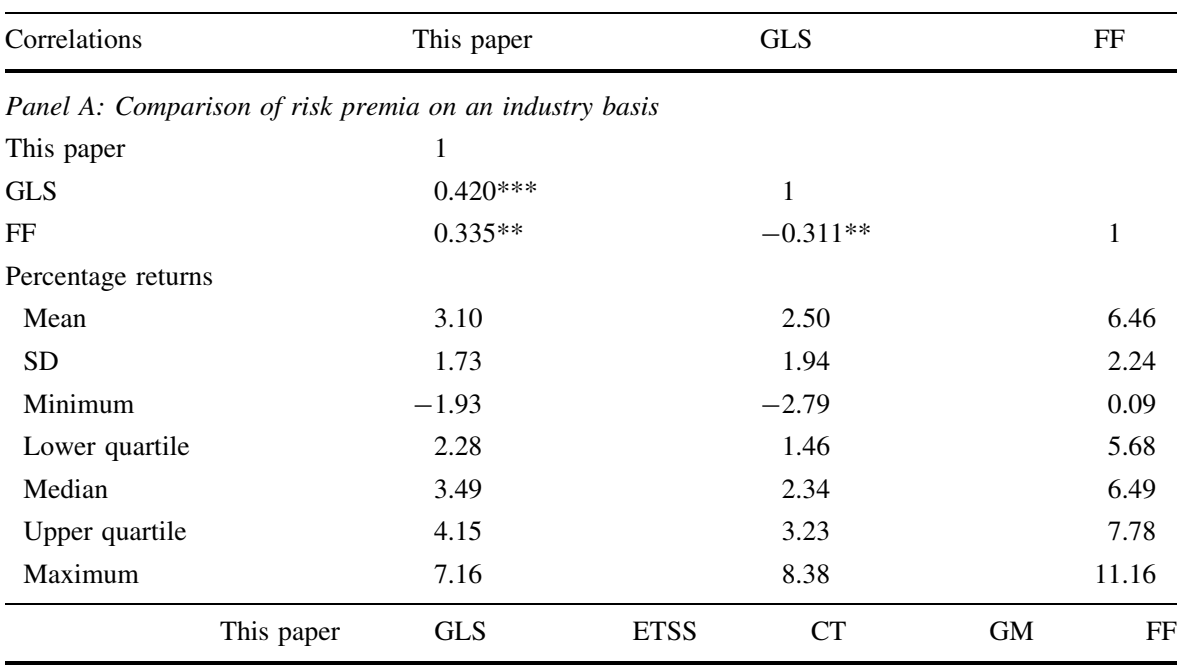

Panel B: Comparison of risk premia on a yearly basis

This paper $\quad 1$

\begin{tabular}{lllllll} 
GLS & $0.918 * * *$ & 1 & & & & \\
ETSS & $0.762 * * *$ & $0.852 * * *$ & 1 & 1 & & \\
CT & 0.203 & $0.576 * *$ & -0.094 & 0.053 & 1 & \\
GM & $0.522 * *$ & 0.339 & 0.467 & -0.123 & 0.158 & 1 \\
FF & $0.329 *$ & 0.210 & -0.035 & -0.123 \\
\hline
\end{tabular}

Sample period Percentage returns

\begin{tabular}{llllllc} 
& $1975-2006$ & $1979-1995$ & $1981-1998$ & $1985-1998$ & $1984-1998$ & $1981-2006$ \\
\hline & 3.83 & 2.49 & 5.31 & 3.40 & 5.52 & 5.96 \\
& 3.53 & 2.80 & 5.60 & 3.44 & 5.50 & 5.23 \\
Common period: & $1985-1995$ & & & & & \\
Mean & 2.98 & 3.17 & 5.66 & 3.49 & 5.53 & 5.35 \\
Lower quartile & 2.42 & 2.70 & 5.25 & 3.10 & 5.20 & -5.56 \\
Median & 3.05 & 3.30 & 5.70 & 3.54 & 5.60 & 13.57 \\
Upper quartile & 3.56 & 3.70 & 6.05 & 3.81 & 6.00 & 17.10
\end{tabular}

Panel A shows the correlation between our estimated risk premia and those from Gebhardt et al. (GLS) (2001) and Fama and French (FF) (1997) three-factor model as well as the statistics for each approach on an industry basis. Panel B shows the correlation between our estimated risk premia and those from Gebhardt et al. (GLS) (2001), Easton et al. (ETSS) (2002), Claus and Thomas (CT) (2001), Gode and Mohanram (GM) (2003) and Fama and French (FF) (1997) as well as the statistics for each approach on a yearly basis. $* * *, * *$, and $*$ denote significance at the 1,5 , and $10 \%$ levels, respectively

In this context, the correlation coefficient is a relatively poor measure of association since the various estimates are not necessarily contemporaneous. The majority of our estimates is based on a December fiscal year-end and is hence based on an April-to-March forecast of returns. Others report estimates based on forecasts in 


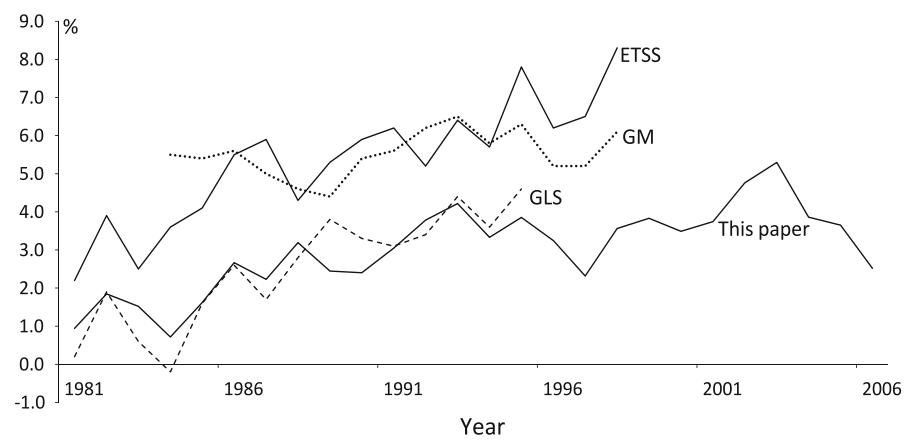

Fig. 2 A comparison of estimates of risk premia. This figure compares our estimates of risk premia based on extended model with Easton et al. (ETSS) (2002), Gebhardt et al. (GLS) (2001) and Gode and Mohanram (GM) (2003)

June, while still others report a January-December estimate. The agreement between the various implied cost of capital estimates is perhaps easier to see in Fig. 2. It shows the time variation in estimates of the risk premia where such estimates are available between 1981 and 2006. We omit Claus and Thomas, whose estimates vary little over the relatively short period of 14 years.

In general, the estimates are highly variable but rising in the early years with some evidence of stabilization in the later years. Although there is a distinct difference in levels between the estimates provided by Easton et al. (2002) and by Gode and Mohanram (2003) and the estimates by Gebhardt et al. (2001), and this paper, there appears to be some agreement between the changes in the estimated risk premia.

We next turn our attention to estimates of growth. Only Easton et al. (2002) and Easton (2004) produce estimates of growth on a year-by-year basis. Figure 3 compares our estimate of the year-on-year growth, with that of Easton et al. (2002), and a forecast of nominal growth produced by the Congressional Budget Office as extracted from Datastream. ${ }^{26}$ Easton et al. (2002) report an average growth rate of just over $10 \%$, though this rate seems implausibly high if considered as growth in perpetuity. ${ }^{27}$ Over the period displayed in the figure (1981-2006), the average forecast growth rate by the Congressional Budget Office was $6.2 \%$, somewhat higher than our estimate of $4 \% .^{28}$ However, we note clear evidence of tracking between the implied forecast from our model and that of the Congressional Budget Office.

The majority of researchers using a terminal value model adopts an inflationary measure of growth in that these researchers use the risk-free rate less a real growth

\footnotetext{
26 The growth estimated by Easton et al. is growth in residual income. However, we would argue that growth in residual income should converge to that of earnings in the long run.

27 In contrast, Easton (2004) reports an average rate of change in abnormal growth in earnings of $2.9 \%$. However, a time-series plot of the change in abnormal growth in earnings with Easton et al. (2002) and our estimates shows no discernible relationship over the common sample period.

${ }^{28}$ Cornell (2010) argues that, because of dilution, we might expect growth in share prices to be about two percentage points less than growth in aggregate earnings.
} 


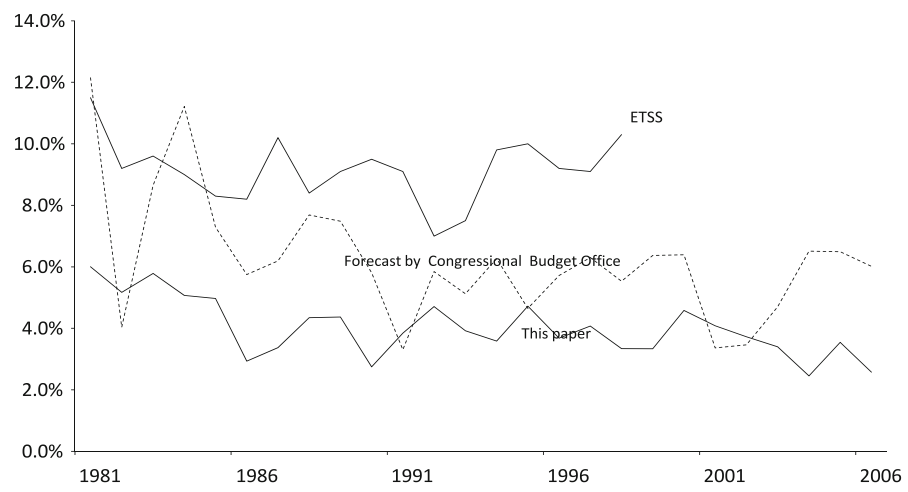

Fig. 3 A comparison of estimates of growth rates. This figure compares our estimates of growth rates based on the extended model with Easton et al. (ETSS) (2002) and the Congressional Budget Office

rate of $3 \%$. Over the period of 1975-2006, the average and median risk free rate, as measured by 5-year US government bond yields less $3 \%$ was 4.4 and $4.1 \%$ respectively, almost identical to our own estimates of implied growth from the modeling. Figure 4 compares the 5-year US government bond rate less $3 \%$, with the annual estimates produced in this paper. Although the 5-year bond rate less $3 \%$ is more volatile, its peaks and troughs roughly coincide with the peaks and troughs in our estimates. Figure 4 suggests that the use of the 5-year bond rate less $3 \%$ is a reasonable proxy for long-term growth in terminal valuations, whose usefulness could probably be improved by imposing a floor at $2 \%$ and a ceiling at $6 \%$.

\section{Conclusion}

We devise and explore a new methodology for estimating simultaneously the implied long-run growth rate and the corresponding implied cost of equity capital. The major difference between our approach and that in prior literature is that ours avoids the necessity to make assumptions about terminal values and consequently about future growth rates. The need for just 1-year-ahead forecast earnings, together with the absence of specific assumptions on dividend payout rates, has enabled us to use a larger data set than previous researchers. It has also enabled estimates of the equity risk premium on a year-by-year basis over a 30-year period.

Our model establishes in analytical form the relationship between future earnings, current price, and accounting fundamentals and the relationship between the implied cost of equity capital and accounting risk factors, such as earnings-toprice, book-to-price, and dividend yield. Finally the relationship between realized returns, forecasts of earnings, and the implied cost of capital facilitates a simple correction for any bias due to analysts' optimism.

The subsequent implementation of the model produces consistent estimates of the cost of capital of between 10.8 and $11.3 \%$ and estimates of the risk premium between 3.1 and $3.9 \%$. Although this value is lower than most previous studies, we include companies with short forecast histories and companies with negative 


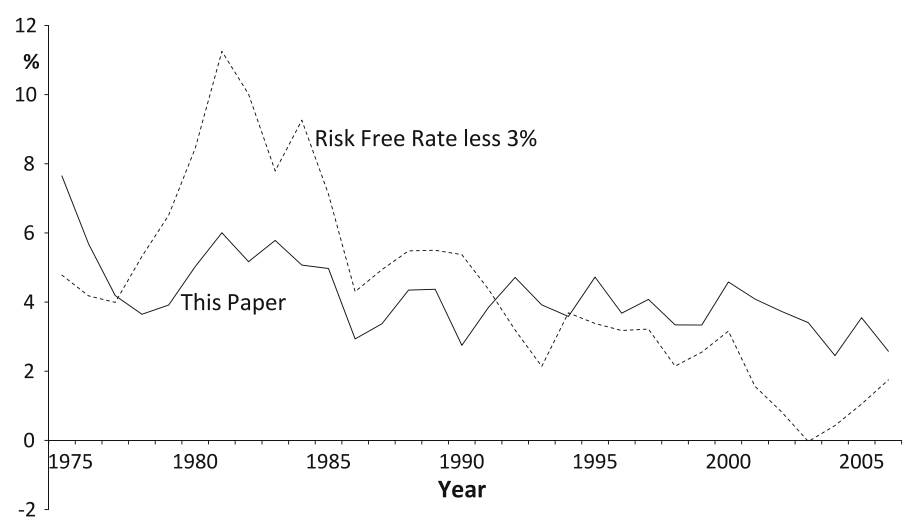

Fig. 4 Estimated growth rate versus the 5-year risk free rate less $3 \%$. This figure compares our estimates of growth rates based on the modified model with 5-year US government bond yields less $3 \%$

forecasts of future earnings. Thus this larger data set reduces the effect of survivorship bias. Our estimate of the long-run nominal growth in share prices is between 4.2 and $4.7 \%$. This is relatively low in historical terms but, interestingly, coincides with the average estimation based on the risk-free rate less $3 \%$, and agrees with the forecasts produced by the Congressional Budget Office. We have compared our estimates of the risk premia and growth with previous research where possible. Here there is evidence of agreement in general trends but rather more disagreement in the actual level. Again though, any comparison is confounded by the differing sample sizes and modeling assumptions.

Acknowledgments The authors appreciate the many helpful comments received from participants at the EAA 2011 and BAA 2011 conferences, faculty at the Victoria University Wellington, University of Otago, University of Exeter, and University of Bristol. We would also like to acknowledge comments from Martin Staehle, Mark Clatworthy, Alan Gregory, and two anonymous reviewers. Finally we would particularly like to express our thanks to the editor, Jim Ohlson, for his many insightful suggestions. Wang is grateful to Inquire-UK for funding support of this project. This article represents the views of the author(s) and not of Inquire UK.

Open Access This article is distributed under the terms of the Creative Commons Attribution License which permits any use, distribution, and reproduction in any medium, provided the original author(s) and the source are credited.

\section{Appendix}

Proof of Eqs. (3) and (4) Since $\alpha_{3}=\alpha_{1}-1$, Eq. (1) implies that

$$
P_{t}=b_{t}+\alpha_{2} e_{t}+\left(\alpha_{1}-1\right)\left(b_{t}+d_{t}\right)+\vartheta_{t} .
$$

No-arbitrage condition, $E_{t}\left[P_{t+1}+d_{t+1}\right]=R P_{t}$, implies

$$
\alpha_{2} E_{t}\left[e_{t+1}\right]+\alpha_{1} E_{t}\left[b_{t+1}+d_{t+1}\right]+E_{t}\left[\vartheta_{t+1}\right]=R P_{t} .
$$

Clean surplus accounting relation, $d_{t+1}=e_{t+1}-\left(b_{t+1}-b_{t}\right)$, then implies that 


$$
E_{t}\left[e_{t+1}\right]=\frac{R}{\left(\alpha_{1}+\alpha_{2}\right)} P_{t}-\frac{\alpha_{1}}{\left(\alpha_{1}+\alpha_{2}\right)} b_{t}-\frac{(1+g)}{\left(\alpha_{1}+\alpha_{2}\right)} \vartheta_{t} .
$$

Replacing $\vartheta_{t}$ by using Eq. (1), $\vartheta_{t}=P_{t}-b_{t}-\alpha_{2} e_{t}-\left(\alpha_{1}-1\right)\left(b_{t}+d_{t}\right)$, and reorganizing, we have

$$
E_{t}\left[e_{t+1}\right]=\delta_{1} P_{t}+\delta_{2} e_{t}+\delta_{3} b_{t}+\delta_{4} b_{t-1}
$$

where

$$
\begin{aligned}
& \delta_{1}=\frac{R-(1+g)}{\left(\alpha_{1}+\alpha_{2}\right)}, \\
& \delta_{2}=\frac{(1+g)\left(\alpha_{1}+\alpha_{2}-1\right)}{\left(\alpha_{1}+\alpha_{2}\right)}, \\
& \delta_{3}=\frac{1+g-\alpha_{1}}{\left(\alpha_{1}+\alpha_{2}\right)}, \\
& \delta_{4}=\frac{(1+g)\left(\alpha_{1}-1\right)}{\left(\alpha_{1}+\alpha_{2}\right)} .
\end{aligned}
$$

We can then write growth rate, cost of capital and valuation parameters in terms of $\delta$ s as

$$
\begin{aligned}
& 1+g=\frac{\left(1+\delta_{2}+\delta_{3}\right)+\sqrt{\left(1+\delta_{2}+\delta_{3}\right)^{2}-4\left(\delta_{2}-\delta_{4}\right)}}{2}, \\
& R=(1+g)\left(1+\frac{\delta_{1}}{1+g-\delta_{2}}\right), \\
& \alpha_{1}=1+\frac{\delta_{4}}{1+g-\delta_{2}}, \\
& \alpha_{2}=\frac{\delta_{2}-\delta_{4}}{1+g-\delta_{2}}
\end{aligned}
$$

Proof of Eq. (8) In the extended model,

$$
\vartheta_{t+1}=(1+g) \vartheta_{t}+\alpha_{4}\left(P_{t}-P_{t-1}+d_{t}-e_{t}\right)+\varepsilon_{v t+1} .
$$

No-arbitrage condition, $E_{t}\left[P_{t+1}+d_{t+1}\right]=R P_{t}$, implies

$$
R P_{t}-\alpha_{2} E_{t}\left[e_{t+1}\right]-\alpha_{1} E_{t}\left[b_{t+1}+d_{t+1}\right]=E_{t}\left[\vartheta_{t+1}\right] .
$$

Clean surplus accounting and Eq. (1) further imply

$$
\begin{aligned}
R P_{t}-\alpha_{1} b_{t}-\left(\alpha_{1}+\alpha_{2}\right) E\left[e_{t+1}\right]= & (1+g)\left(P_{t}-\alpha_{1} b_{t}-\alpha_{2} e_{t}-\alpha_{3} d_{t}\right)+\alpha_{4}\left(P_{t}-P_{t-1}\right. \\
& \left.+d_{t}-e_{t}\right),
\end{aligned}
$$


or

$$
\begin{aligned}
E_{t}\left[e_{t+1}\right]= & \frac{R-(1+g)-\alpha_{4}}{\left(\alpha_{1}+\alpha_{2}\right)} P_{t}+\frac{(1+g) \alpha_{2}+\alpha_{4}}{\left(\alpha_{1}+\alpha_{2}\right)} e_{t}+\frac{g \alpha_{1}}{\left(\alpha_{1}+\alpha_{2}\right)} b_{t} \\
& +\frac{(1+g)\left(\alpha_{1}-1\right)-\alpha_{4}}{\left(\alpha_{1}+\alpha_{2}\right)} d_{t}+\frac{\alpha_{4}}{\left(\alpha_{1}+\alpha_{2}\right)} P_{t-1} .
\end{aligned}
$$

Applying clean surplus identity, $d_{t}=e_{t}-\left(b_{t}-b_{t-1}\right)$, the above can be rewritten as

$$
E\left[e_{t+1}\right]=\delta_{1}^{\prime} P_{t}+\delta_{2}^{\prime} e_{t}+\delta_{3}^{\prime} b_{t}+\delta_{4}^{\prime} b_{t-1}+\delta_{5}^{\prime} P_{t-1},
$$

where

$$
\begin{aligned}
& \delta_{1}^{\prime}=\frac{R-(1+g)}{\left(\alpha_{1}+\alpha_{2}\right)}-\delta_{5}^{\prime}, \quad \delta_{2}^{\prime}=\frac{(1+g)\left(\alpha_{1}+\alpha_{2}-1\right)}{\left(\alpha_{1}+\alpha_{2}\right)}, \quad \delta_{31}^{\prime}=\frac{1+g-\alpha_{1}}{\alpha_{1}+\alpha_{2}}+\delta_{5}^{\prime}, \\
& \delta_{4}^{\prime}=\frac{(1+g)\left(\alpha_{1}-1\right)}{\left(\alpha_{1}+\alpha_{2}\right)}-\delta_{5}^{\prime}, \quad \delta_{5}^{\prime}=\frac{\alpha_{4}}{\left(\alpha_{1}+\alpha_{2}\right)} .
\end{aligned}
$$

These imply

$$
\begin{aligned}
1+g & =\frac{1+\delta_{2}^{\prime}+\delta_{3}^{\prime}-\delta_{5}^{\prime}+\sqrt{\left(1+\delta_{2}^{\prime}+\delta_{3}^{\prime}-\delta_{5}^{\prime}\right)^{2}-4\left(\delta_{2}^{\prime}-\delta_{4}^{\prime}-\delta_{5}^{\prime}\right)}}{2} \\
R & =(1+g)\left(1+\frac{\delta_{1}^{\prime}+\delta_{5}^{\prime}}{1+g-\delta_{2}^{\prime}}\right) \\
\alpha_{1} & =1+\frac{\delta_{4}^{\prime}+\delta_{5}^{\prime}}{(1+g)-\delta_{2}^{\prime}} \\
\alpha_{2} & =\frac{\delta_{2}^{\prime}-\delta_{4}^{\prime}-\delta_{5}^{\prime}}{(1+g)-\delta_{2}^{\prime}} \\
\alpha_{4} & =\frac{(1+g) \delta_{5}^{\prime}}{1+g-\delta_{2}^{\prime}} .
\end{aligned}
$$

\section{References}

Ball, R., Kothari, S. P., \& Robin, A. (2000). The effect of international institutional factors on properties of accounting earnings. Journal of Accounting and Economics, 29, 1-51.

Bogle, J. C. (1999). Common sense on mutual funds. New York: Wiley.

Botosan, C., \& Plumlee, M. A. (2002). A re-examination of disclosure level and expected cost of equity capital. Journal of Accounting Research, 40, 21-40.

Botosan, C., \& Plumlee, M. A. (2005). Assessing alternative proxies for the expected risk premium. The Accounting Review, 80, 21-53.

Claus, J., \& Thomas, J. (2001). Equity premia as low as three percent? Evidence from analysts' earnings forecasts for domestic and international stock markets. The Journal of Finance, 56, 1629-1666.

Cornell, B. (2010). Economic growth and equity investing. Financial Analysts Journal, 66, 54-64.

Dimson, E., Marsh, P., \& Staunton, M. (2011). Credit Suisse Global Investment Returns Sourcebook 2011. Zurich: Credit Suisse Research Institute. 
Easton, P. D. (2004). PE ratios, PEG ratios, and estimating the implied expected rate of return on equity capital. The Accounting Review, 79, 73-96.

Easton, P. D. (2009). Estimating the cost of capital implied by market price and accounting data. Foundations and Trends in Accounting, 2, 241-364.

Easton, P. D., \& Sommers, G. (2007). Effect of analysts' optimism on estimates of the expected rate of return implied by earnings forecasts. Journal of Accounting Research, 45, 983-1016.

Easton, P. D., Taylor, G., Shroff, P., \& Sougiannis, T. (2002). Using forecasts of earnings to simultaneously estimate growth and the rate of return on equity investment. Journal of Accounting Research, 40, 657-676.

Elton, E. (1999). Expected return, realized return and asset pricing tests. Journal of Finance, 54, 1199-1220.

Fama, E., \& French, K. (1997). Industry costs of equity. Journal of Financial Economics, 43, $153-193$.

Feltham, G., \& Ohlson, J. (1995). Valuation and clean surplus accounting for operating and financial activities. Contemporary Accounting Research, 11, 689-731.

Feltham, G., \& Ohlson, J. (1996). Uncertainty resolution and the theory of depreciation measurement. Journal of Accounting Research, 34, 209-234.

Gebhardt, W., Lee, C., \& Swaminathan, B. (2001). Toward an implied cost of capital. Journal of Accounting Research, 39, 135-176.

Glassman, J. K., \& Hassett, K. A. (1998, March 30). Are stock overvalued? Not a chance. Wall Street Journal.

Gode, D., \& Mohanram, P. (2003). Inferring cost of capital using the Ohlson-Juettner model. Review of Accounting Studies, 8, 339-431.

Gordon, J., \& Gordon, M. (1997). The finite horizon expected return model. Financial Analysts Journal, 53, 52-61.

Gow, I. D., Ormazabal, G., \& Taylor, D. J. (2010). Correcting for cross-sectional and time-series dependence in accounting research. The Accounting Review, 85, 483-512.

Ibbotson Associates. (2006). Stocks, bonds, bills and inflation, valuation edition 2006 yearbook.

Khan, M., \& Watts, R. (2009). Estimation and validation of a firm-year measure of conservatism. Journal of Accounting and Economics, 48, 132-150.

Liu, J., Nissim, D., \& Thomas, J. (2002). Equity valuation using multiples. Journal of Accounting Research, 40, 135-172.

Lundholm, R., \& Sloan, R. (2007). Equity valuation and analysis (2nd ed.). New York: McGraw Hill Irwin.

Mcinnis, J. (2010). Earnings smoothness, average returns, and implied cost of equity capital. The Accounting Review, 85, 315-341.

Mehra, R., \& Prescott, E. C. (1985). The equity premium: A puzzle. Journal of Monetary Economics, 15, $145-161$.

Miller, M., \& Modigliani, F. (1961). Dividend policy, growth and the valuation of shares. Journal of Business, 34, 411-433.

Nekrasov, A., \& Ogneva, M. (2011). Using earnings forecasts to simultaneously estimate firm-specific cost of equity and long-term growth. Review of Accounting Studies, 16, 414-457.

O'Hanlon, J., \& Steele, A. (2000). Estimating the equity risk premium using accounting fundamentals. Journal of Business Finance and Accounting, 27, 1051-1084.

Ohlson, J. (1995). Earnings, book values, and dividends in security valuation. Contemporary Accounting Research, 11, 661-687.

Ohlson, J., \& Juettner-Nauroth, B. E. (2005). Expected EPS and EPS growth as determinants of value. Review of Accounting Studies, 10, 349-365.

Pastor, L., Sinha, M., \& Swaminathan, B. (2008). Estimating the intertemporal risk-return tradeoff using the implied cost of capital. The Journal of Finance, 63, 2859-2897.

Penman, S., \& Zhang, X.-J. (2002). Accounting conservatism, the quality of earnings, and stock returns. The Accounting Review, 77, 237-264.

Petersen, M. A. (2009). Estimating standard errors in finance panel data sets: comparing approaches. The Review of Financial Studies, 22, 435-480.

Pope, F. P., \& Wang, P. (2005). Earnings components, accounting bias and equity valuation. Review of Accounting Studies, 10, 387-407.

Richardson, S., Tuna, I., \& Wysocki, P. (2010). Accounting anomalies and fundamental analysis: a review of recent research advances. Journal of Accounting and Economics, 50, 410-454. 
Siegel, J., \& Thaler, R. H. (1997). The equity risk premium puzzle. Journal of Economic Perspectives, 11, 191-200.

Smith, C., \& Watts, R. (1992). The investment opportunity set and corporate financing, dividend and compensation policies. Journal of Financial Economics, 32, 263-292.

Welch, I. (2000). Views of financial economists on the equity premium and on professional controversies. Journal of Business, 73, 501-537.

White, H. (1980). A heteroscedasticity-consistent covariance estimator and a direct test for heteroscedasticity. Econometrica, 48, 817-838. 